\title{
Application of Organic and Inorganic Fertilizers Affects the Growth and Biomass Semanggi (Marsilea crenata Presl.)
}

\author{
Mustika Tripatmasari*1,2 ${ }^{2}$ Ariffin ${ }^{3}$, Ellis Nihayati ${ }^{3}$, Mangestuti Agil ${ }^{4}$ \\ ${ }^{1}$ Postgraduate Program, Faculty of Agriculture, Brawijaya University, Malang, Indonesia \\ ${ }^{2}$ Faculty of Agriculture, University of Trunojoyo Madura, Indonesia \\ ${ }^{3}$ Faculty of Agriculture,University of Brawijaya Malang, Indonesia \\ ${ }^{4}$ Faculty of Pharmacy, Airlangga University, Indonesia
}

Received: November 3, 2020. Revised: April 14, 2021. Accepted: May 13, 2021. Published: May 17, 2021.

\begin{abstract}
Semanggi (Marsilea crenata Presl.) is one of the aquatic plants that have been widely used by the community as food and medicinal raw materials. One of the important factors in cultivating clover is optimal fertilizer management. The incorporation of organic and inorganic nutrients has an effect on soil fertility has been repeatedly demonstrated in several studies, but there are not specific guidelines on clover cultivation. The challenge now is to combine organic matter of different qualities with inorganic fertilizers to optimize nutrient availability for the clover plant. The results of research on clover cultivation have also not been widely carried out. Therefore, it is very important to do this research with the aim of knowing the optimal effect of organic (cow manure) and inorganic (nitrogen, potassium) fertilizers on the growth and yield of clover (Marsilea crenata Presl.). The research was conducted at the Screen House of the Faculty of Agriculture, Brawijaya University. The study was designed using a non-factorial randomized block design (RBD) with 8 (eight) treatment combinations of soil types and fertilization [inorganic $(\mathrm{N}, \mathrm{K})$ cow manure organic fertilizer (CM)], namely: P0 = soil, without fertilizer; P1 = soil, $138 \mathrm{~kg} \mathrm{~N} \mathrm{ha}^{-1} ; \mathbf{P 2}=$ soil, $136 \mathrm{~kg} \mathrm{~K} \mathrm{ha}^{-1} ; \mathbf{P 3}=$ soil, $\mathrm{N}$ and $K, 138$ and $136 \mathrm{~kg} \mathrm{ha}^{-1} ; \mathrm{P4}=$ soil, $20 \times 10^{3} \mathrm{~kg}$ of cow manure ha-1 $;$ P5 = soil, 20x10 $\mathrm{kg}^{3}$ of cow manure ha-1, 138 $\mathrm{kg} \mathrm{N} \mathrm{ha}^{-1} ; \mathbf{P 6}=$ soil, $20 \times 10^{3} \mathrm{~kg}$ of cow manure $\mathrm{ha}^{-1}, 136 \mathrm{~kg}$ $\mathrm{K} \mathrm{ha}^{-1}$; P7 = soil, $20 \times 10^{3} \mathrm{~kg}$ of cow manure $\mathrm{ha}^{-1}, \mathrm{~N}$ and $\mathrm{K}$, 138 and $136 \mathrm{~kg} \mathrm{ha}^{-1}$ with 3 replications, so that 24 experimental units were obtained. Each experimental unit consisted of 5 plants. Growth observations were observed destructively at the ages of $4,8,12,16,20,24,28,32$ days after planting (DAP). The results showed that there was an increase in the growth and yield of biomass in the soil combination, 20x10 $\mathrm{kg}^{3}$ of cow manure $\mathrm{ha}^{-1}(\mathbf{P 4})$ was compared with the treatment without the addition of organic fertilizers (cow manure) on plant growth and yield parameters, such as stolon length $(74.78 \mathrm{~cm})$, number of
\end{abstract}

leaves (160.44), leaf area $\left(1379.28 \mathrm{~cm}^{2}\right)$, root length $(23.85$ cm), stomata density and number of stomata (13.25); Stomata width $(10.87 \mathrm{~cm})$; Stomata length $(19.76 \mathrm{~cm})$, leaf fresh weight $(12,907 \mathrm{~g})$, leaf dry weight $(1,802 \mathrm{~g})$, total fresh weight $210,830 \mathrm{~g}$, total dry weight $7,823 \mathrm{~g}$, leaf harvest fresh weight $(64.19 \mathrm{~g})$; stalk $(130.54 \mathrm{~g})$; $\operatorname{root}(79.75$ g); total $274.48 \mathrm{~g}$ ), harvest dry weight of leaves (11.36 g); stalk (24.88 g); root $(9.55 \mathrm{~g})$; a total of $45.78 \mathrm{~g})$ and the

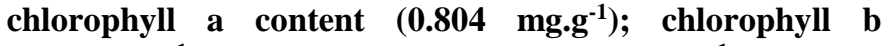

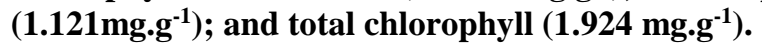

Keywords: organic fertilizer, inorganic, biomass, semanggi

\section{INTRODUCTION}

Semanggi (Marsilea crenata Presl.) is one of the aquatic plants that has been widely used by the community as food. Semanggi (Marsilea sp.), Is one of the ferns that usually grows in muddy environments, moist soils, watery places or wet habitats such as rice fields [1], ditches and shallow puddles [2],[3], lakes under full sun and shady conditions have a cosmopolitan distribution, but are rarely distributed in subtropical areas.

So far, people know that the clover plant is a lowland rice weed, some of which use it as a vegetable, medicinal plant [4], and also as a phytoremediation plant [5]-[7]. Indonesian people are more familiar with semanggi as one of the typical culinary delights of the city of Surabaya, East Java Province which has been known since ancient times as "Semanggi Suroboyo". The clover plant commonly consumed by the people of Surabaya and its surroundings is Marsilea crenata Presl [5]. Apart from that, it also has plant-derived phytochemical compounds, phytoestrogens are naturally occurring estrogenic compounds that have structural similarities to estrogens [8]-[11]. So that estrogenic activity can play a role in preventing cancer, reducing menopausal symptoms, and other health effects [12].

This clover plant can be found in rice fields in Kendung Village, Sememi Village, Benowo District. Initially this plant for the people of Kendung Village was a wild plant between rice fields. But now it is finally planted as a substitute for rice. 
So cultivated by the people of the area. Clover cultivation techniques applied by farmers in Kendung Village, Sememi Village, Benowo District, Surabaya is still the same as rice field cultivation, so it is still not able to produce biomass optimally. Whereas when the clover plant is used as an alternative food and can be used as raw material for medicine, what is prioritized is the high amount of plant biomass. Meanwhile, the need for consumption is quite large, so that it cannot be fulfilled. Currently, clover plants can only be found in a few areas, for example in the West Surabaya area. Apart from the fact that not many farmers are interested in cultivating clover, another factor that is no less important is the nutrient factor.

The availability of nutrients in the soil through proper fertilizer management for medicinal plant species (ethno medicinal) is very important as a step in increasing plant biomass yield and maintaining quality [13]. The main essential nutrients for $\mathrm{N}, \mathrm{P}$, and $\mathrm{K}$ plants as much as 135,60 and $132 \mathrm{~kg}$ $\mathrm{ha}^{-1}$ can increase optimal production of Centella asiatica L. Urb. [14], increase growth and production of dry weight consistently [15], sufficiency Ammonium nutrients from nitrogen can increase the absorption of phosphorus and the use of inorganic fertilizers (N, P, K) continuously causes fertilizers to accumulate in the soil, so that the soil becomes hard and difficult to process ([16], potassium is not available in sufficient quantity es as well. resulting in low nitrogen and phosphorus efficiency [17]. To overcome the accumulation of fertilizers into the soil due to the continuous use of inorganic fertilizers (N, P, K), organic fertilization can be done, so as to improve the physical, chemical, and biological properties of the soil [18] and efficient use of fertilizers [19]. The main nutrient elements needed by plants are $\mathrm{N}$ and $\mathrm{K}$. Nitrogen is known as one of the most limiting nutrients for plant growth and can be added with organic matter (eg animal manure, crop residues, green manure, etc.) or from inorganic fertilizers (urea, ammonia, nitrates, etc.). Nitrogen can increase growth during the vegetative phase and protein synthesis. According to [20] nitrogen is applied to plants to be taken over by leaves, because it will make the leaves grow well. Sufficient nitrogen in the soil will make plants look greener, meaning that nitrogen plays a role in the formation of chlorophyll for photosynthesis. Meanwhile, potassium plays a role in physiological processes and plant metabolism, such as regulating respiration through stomata, enzymatic activity in starch formation, increasing resistance to drought and disease. In addition, potassium can improve the quality of plants, one of which is to increase the content of starch, oil, or other secondary metabolite compounds. Besides the two elements mentioned above, organic matter such as plant residues can increase $\mathrm{N}$ mineralization in the soil [21]-[24]. Changes in N in the soil will increase yields by $26-41 \%$ [25] and is one of the main plant nutrients involved in chlorophyll synthesis, and affects stomata conductance and photosynthetic. Farmers have traditionally made use of various types of organic matter to maintain or increase the fertility and productivity of their agricultural land. To improve the quality of plants, especially medicinal and aromatic plants, it is mostly done by using organic fertilizers to be acceptable rather than chemical fertilizers [26]-[30]. The beneficial effects of the application of organic fertilizers on the growth and yield of millet and wheat were demonstrated by reported that the addition of compost can significantly increase the productivity of M.enthaspicata, M. pulegium and M. longifolia, where an increase in composting rates from 3.5 to $7.5 \mathrm{Mg}$ ha-1 resulted in a significant increase in all growth parameters [13]. A significant increase in yield was also reported through the addition of poultry manure to Curculigo orchioides Gaertn, and $C$. asiatica. The effect of organic and inorganic fertilizers on the growth and yield of various medicinal plants has been studied by several researchers [31]-[40], the complete substitution of inorganic fertilizers with organic fertilizers such as vermicompost, or farmyard manure. (FYM), however, is not recommended because the nutrient concentration of organic fertilizers is generally low compared to inorganic fertilizers. This requires the application of very large amounts of organic fertilizer to meet the nutritional needs of the plant.

Based on some of the scientific reviews above, one of the efforts to increase the biomass of the clover plant is in fulfilling the right nutrients. Meanwhile, the results of research on the cultivation of clover plants that are in accordance with Good Agricultural Practices (GAP) have not been widely carried out. Therefore it is necessary to conduct research with the aim of obtaining the influence of nitrogen, potassium and optimal cow manure on the growth and yield of biomass of clover (Marsilea crenata Presl.). to support the development of clover plants in Indonesia with good cultivation techniques.

\section{MATERIAL AND METHOD}

The research was conducted in a greenhouse in the experimental garden of Brawijaya University Malang, East Java, Indonesia ( $7^{\circ} 56^{\prime} 19.6^{\prime \prime}$ South Latitude and $112^{\circ} 37^{\prime} 05.1^{\prime \prime}$ East Longitude at an altitude of 506 meters above sea level). The research was conducted in March-May 2020. The materials used by clover seeds were obtained from the Kendung village cultivation center, Sememi Village, Benowo District, Surabaya City, East Java, Indonesia, cow manure, urea, $\mathrm{KCl}$, alluvial soil, planting tubs/pots, rulers, digital cameras, and stationery.

The study was designed using a non-factorial randomized block design (RBD) with 8 (eight) treatment combinations of soil types and fertilization [inorganic $(\mathrm{N}, \mathrm{K})$ cow manure organic fertilizer $(\mathrm{CM})]$, namely: $\mathrm{P} 0=$ soil, without fertilizer; $\mathrm{P} 1=$ soil, $138 \mathrm{~kg} \mathrm{~N} \mathrm{ha}^{-1} ; \mathrm{P} 2=$ soil, $136 \mathrm{~kg} \mathrm{~K} \mathrm{ha}^{-1} ; \mathrm{P} 3=$ soil, $\mathrm{N}$ and $\mathrm{K}, 138$ and $136 \mathrm{~kg} \mathrm{ha}^{-1} ; \mathrm{P} 4=$ soil, $20 \times 10^{3} \mathrm{~kg}$ of cow manure ha- ${ }^{-1} ; \mathrm{P} 5=$ soil, $20 \times 10^{3} \mathrm{~kg}$ of cow manure ha-1 $138 \mathrm{~kg}$ $\mathrm{N} \mathrm{ha}^{-1} ; \mathrm{P} 6=$ soil, $20 \times 10^{3} \mathrm{~kg}$ of cow manure ha ${ }^{-1}, 136 \mathrm{~kg} \mathrm{~K}^{-}$ ${ }^{1} ; \mathrm{P} 7=$ soil, $20 \times 10^{3} \mathrm{~kg}$ of cow manure ha ${ }^{-1}, \mathrm{~N}$ and $\mathrm{K}, 138$ and $136 \mathrm{~kg} \mathrm{ha}^{-1}$ with 3 replications, so that 24 experimental units were obtained.

Each treatment unit contained five plastic pots measuring $42 \mathrm{~cm}, 32 \mathrm{~cm}$ wide, and $14 \mathrm{~cm}$ high, filled with alluvial soil weighing $7 \mathrm{~kg}$ (P0-P7), and some were added with organic fertilizer (cow manure) as much as $800 \mathrm{~g} /$ pot. (Planting medium according to treatment P4-P7). The number of plants per pot of 8 plants, so the total crop is 960 plants. Furthermore, each treatment consists of 5 plants, and each observation requires 3 sample plants to be observed destructively. Observations were made 4, 8, 12, 16, 20, 24, 28, 32 days after planting (DAP). 
Measurement of growth components is observed by taking samples of plants produced by each plant in each experimental unit, including 1) Stolon length $(\mathrm{cm})$. The stolon length is calculated from the starting point of growth. 2). The number of leaves counted the number of leaves (strands) that open perfectly. 3). Leaf area $\left(\mathrm{cm}^{2}\right)$ by taking clover plant leaves is then measured by the formula Leaf Area $\left(\mathrm{cm}^{2}\right)=$ Total Paper Weight (Wr) (g) / Total Replica Weight (Wt) (g) x Paper Area $\left.\left(\mathrm{cm}^{2}\right) 4\right)$. Root length $(\mathrm{cm})$ is done by measuring the longest root using a ruler from the base of the root to the tip of the root. 5). Stomata density, the preparation of preparations for stomata observation was carried out by the stomata printing method [41]; namely, the lower surface of the leaves was smeared with nail polish and allowed to dry. Then the nail polish is peeled off using insulation and placed on a glass object. The preparations were observed under an Olympus BX 51 computer microscope and an Olympus DP 24 camera with a 400x magnification.

Measurement of production components is observed by taking sample plants produced by each individual plant in each experimental unit, including 1). Leaf fresh weight (g), leaf fresh weight measurements were carried out once every 4 days for 32 days after planting (DAP) by weighing the prunings (leaves, stalks, roots, total) produced by each plant. 2). Leaf dry weight $(\mathrm{g})$, leaf dry weight measurement was carried out once every 4 days for 32 days after planting (DAP) by weighing the dry weight of the prunings (leaves, stalks, roots, total) which had been oven at $105^{\circ} \mathrm{C}$ for one day. 3). Total fresh weight $(\mathrm{g})$, measurement of fresh weight (leaf, stalk, root, complete) is carried out every 4 days for 32 days after planting (DAP) by weighing the results of the trimmings (leaves, stalks, roots, total) produced each time. Individual plants. 4). Total dry weight (g), measurement of dry weight (leaf, stalk, root, total) is carried out every 4 days for 32 days after planting (DAP) by weighing the dry weight of the prunings (leaves, stalks, roots, total) that have been oven at $105 \mathrm{o} \mathrm{C}$ for 1 day. 5). Fresh harvest weight (g), measurement of wet leaf weight is carried out at harvest by weighing the fresh weight (leaves, stalks, roots, total) produced by each plant. 6). Harvest dry weight (g), measurement of dry leaf weight was carried out at harvest by weighing the dry weight (leaves, stalks, roots, total) which had been oven at $105 \mathrm{o} \mathrm{C}$ for 1 day. 7). Chlorophyll content, analysis methods of chlorophyll $\mathrm{a}$ and $\mathrm{b}$ [42]. Weight $1 \mathrm{~g}$ of clover leaves then extracted (crushed with a porcelain cup) with $85 \%$ acetone solvent in a centrifuge. Filter and take the filtrate. Add the filtrate to a $100 \mathrm{ml}$ measuring flask. Then add the same solvent so that the solution becomes $100 \mathrm{ml}-$ spectrophotometer at $\lambda 645 \mathrm{~nm}$ and $\lambda 663 \mathrm{~nm}$. The amount of chlorophyll is calculated using the chlorophyll formula. $\mathrm{a}=$ 12.7 D-663 - 2.69 D-645 (mg / l). chlorophyll b = 22.9 D-645 - 4.68 D-663 (mg / l). Chlorophyll Total = 20.2 D-645 + 8.02 D-663 (mg / 1). The chlorophyll a or b levels were then converted into $\mathrm{mg} \cdot \mathrm{g}^{-1}$ of leaves.

\section{Data analysis}

Data analysis using analysis of variance (ANOVA) was carried out to examine the effect of treatment combinations on plant growth. If there is a significant effect on the treatment, it is followed by a different test using LSD at the 5\% level [43]

\section{RESULTS AND DISCUSSION}

\section{Response of organic and inorganic fertilizers to the Growth Components Stolon lengths}

The results of the analysis of variance showed that the addition of organic and inorganic fertilizers had a significant effect on the length of the stolons at the observation ages of $12,16,20,24$, and 32 DAP $(p<0.05)$. The total size of the stolons is presented in Table 2. Based on the presentation of Table 2 above that at the age of $12 \mathrm{DAP}$, the length of the

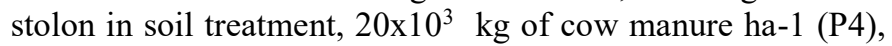
is $8.80 \mathrm{~cm}$ longer than the soil treatment, without fertilizer (P0), soil treatment, $138 \mathrm{~kg} \mathrm{~N} h a^{-1}(\mathrm{P} 1)$, soil treatment, $136 \mathrm{~kg}$ $\mathrm{K} \mathrm{ha}^{-1}(\mathrm{P} 2)$, soil treatment, $\mathrm{N}$ and $\mathrm{K}, 138$ and $136 \mathrm{~kg} \mathrm{ha}^{-1}(\mathrm{P} 3)$, soil treatment, $20 \times 10^{3} \mathrm{~kg}$ of cow manure $\mathrm{ha}^{-1}, 138 \mathrm{~kg} \mathrm{~N} \mathrm{ha}^{-1}$

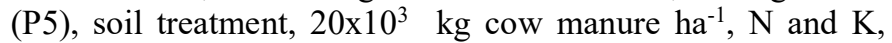
138 and $136 \mathrm{~kg} \mathrm{ha}^{-1}(\mathrm{P} 7)$, but not different from stolon length in soil treatment, $20 \times 10^{3} \mathrm{~kg}$ cow manure fertilizer ha ${ }^{-1}, 136 \mathrm{~kg}$ $\mathrm{K} \mathrm{ha}^{-1}$ (P6). Furthermore, the lowest stolon length was found in soil treatment, $136 \mathrm{~kg} \mathrm{~K} \mathrm{ha}^{-1}$ (P2) of $3.96 \mathrm{~cm}$.

Stolon length at observation age 16 DAP, stolon length in soil treatment, $20 \times 10^{3} \mathrm{~kg}$ of cow manure ha-1 (P4) is 16.67 $\mathrm{cm}$ longer than soil treatment, without fertilizer (P0), soil treatment, $138 \mathrm{~kg} \mathrm{~N} \mathrm{ha}^{-1}$ (P1), soil treatment, $136 \mathrm{~kg} \mathrm{~K} \mathrm{ha}^{-1}$

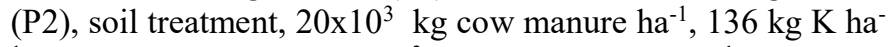

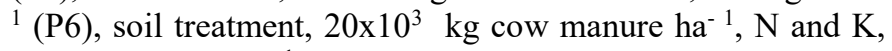
138 and $136 \mathrm{~kg} \mathrm{ha}^{-1}(\mathrm{P} 7)$, but not different from the length of the stolons in soil treatment, $\mathrm{N}$ and $\mathrm{K}, 138$ and $136 \mathrm{~kg} \mathrm{ha}^{-1}$ (P3), soil treatment, $20 \times 10^{3} \mathrm{~kg}$ of cow manure ha-1, $138 \mathrm{~kg} \mathrm{~N}$ $\mathrm{ha}^{-1}$ (P5). Furthermore, the lowest stolon length was found in soil treatment, without fertilizer ( $\mathrm{P} 0)$ (control) of $7.62 \mathrm{~cm}$.

At the age of 20 DAP observations, soil treatment, $20 \times 10^{3}$ $\mathrm{kg}$ of cow manure ha- ${ }^{-1}$ (P4) of $29.37 \mathrm{~cm}$ produced a longer stolon than soil treatment, without fertilizer (P0), soil treatment, $138 \mathrm{~kg} \mathrm{~N}^{-1}(\mathrm{P} 1)$ and soil treatment, $20 \times 10^{3} \mathrm{~kg}$ of cow manure ha ${ }^{-1}, \mathrm{~N}$ and $\mathrm{K}, 138$ and $136 \mathrm{~kg}$ ha-1 (P7), but not different from soil treatment, $136 \mathrm{~kg} \mathrm{~K} \mathrm{ha}^{-1}(\mathrm{P} 2)$, soil treatment, $\mathrm{N}$ and $\mathrm{K}, 138$ and $136 \mathrm{~kg} \mathrm{ha}^{-1}(\mathrm{P} 3)$, soil treatment, $20 \times 10^{3} \mathrm{~kg}$ cow manure $\mathrm{ha}^{-1}, 138 \mathrm{~kg} \mathrm{~N} \mathrm{ha}^{-1}$ (P5) and soil treatment, $20 \times 10^{3} \mathrm{~kg}$ cow manure ha-1, $136 \mathrm{~kg} \mathrm{~K} \mathrm{ha}^{-1}$ (P6). Furthermore, the lowest stolon length was found in soil treatment, without fertilizer (P0) of $14.38 \mathrm{~cm}$.

Stolon length at observation age 24 DAP soil treatment, $20 \times 10^{3} \mathrm{~kg}$ of cow manure ha- $\mathrm{h}^{-1}(\mathrm{P} 4)$ of $41.08 \mathrm{~cm}$ produced longer stolons than soil treatment, without fertilizer (P0), soil treatment, $138 \mathrm{~kg} \mathrm{~N}^{-1}(\mathrm{P} 1)$, soil treatment, $136 \mathrm{~kg} \mathrm{~K} \mathrm{ha}^{-1}$ (P2), soil treatment, $\mathrm{N}$ and $\mathrm{K}, 138$ and $136 \mathrm{~kg} \mathrm{ha}^{-1}$ (P3), soil treatment, $20 \times 10^{3} \mathrm{~kg}^{3}$ cow manure ha ${ }^{-1}, 138 \mathrm{~kg} \mathrm{~N}^{-1}$ (P5) and

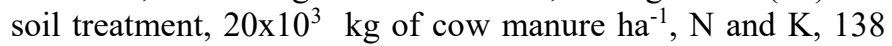
and $136 \mathrm{~kg} \mathrm{ha}^{-1}(\mathrm{P} 7)$, but not different from soil treatment, $20 \times 10^{3} \mathrm{~kg}$ of cow manure $\mathrm{ha}^{-1}, 136 \mathrm{~kg} \mathrm{~K}$ ha-1 (P6). Furthermore, the lowest stolon length was found in soil treatment, without fertilizer (P0) of $19.25 \mathrm{~cm}$.

Stolon length at the age of observation 28 DAP soil treatment, $20 \times 10^{3} \mathrm{~kg}$ of cow manure $\mathrm{ha}^{-1}(\mathrm{P} 4)$ of $56.16 \mathrm{~cm}$ resulted in a longer stolon than soil treatment, without fertilizer (P0), soil treatment, $138 \mathrm{~kg} \mathrm{~N}$ ha $^{-1}$ (P1), soil treatment, $136 \mathrm{~kg} \mathrm{~K} \mathrm{ha}^{-1}(\mathrm{P} 2)$, soil treatment, $\mathrm{N}$ and $\mathrm{K}, 138$ and $136 \mathrm{~kg} \mathrm{ha}^{-1}(\mathrm{P} 3)$, soil treatment, $20 \times 10^{3} \mathrm{~kg}$ cow manure 
ha-1, $138 \mathrm{~kg} \mathrm{~N} \mathrm{ha}^{-1}$ (P5), soil treatment, 20x10 ${ }^{3} \mathrm{~kg}$ of cow manure ha ${ }^{-1}, 136 \mathrm{~kg} \mathrm{~K} \mathrm{ha}^{-1}(\mathrm{P} 6)$ and soil treatment, $20 \times 10^{3} \mathrm{~kg}$ of cow manure ha-1, $\mathrm{N}$ and $\mathrm{K}, 138$ and $136 \mathrm{~kg} \mathrm{ha}^{-1}$ (P7). Furthermore, the lowest stolon length was found in soil treatment, without fertilizer $(\mathrm{P} 0)$ of $24.39 \mathrm{~cm}$.

Stolon length at the age of observation 32 DAP soil treatment, $20 \times 10^{3} \mathrm{~kg}$ of cow manure ha ${ }^{-1}(\mathrm{P} 4)$ produced the longest stolon of $74.78 \mathrm{~cm}$ compared to soil treatment, without fertilizer (P0), soil treatment, $138 \mathrm{~kg} \mathrm{~N} \mathrm{ha}^{-1}(\mathrm{P} 1)$, soil treatment, $\mathrm{N}$ and $\mathrm{K}, 138$ and $136 \mathrm{~kg} \mathrm{ha}^{-1}(\mathrm{P} 3)$, and soil treatment, $20 \times 10^{3} \mathrm{~kg}$ of cow manure $\mathrm{ha}^{-1}, \mathrm{~N}$ and $\mathrm{K}, 138$ and $136 \mathrm{~kg} \mathrm{ha}^{-1}(\mathrm{P} 7)$, but not different from stolon length in soil treatment, $136 \mathrm{~kg} \mathrm{~K} \mathrm{ha}^{-1}(\mathrm{P} 2)$, soil treatment, $20 \times 10^{3} \mathrm{~kg}$ cow manure $\mathrm{ha}^{-1}, 138 \mathrm{~kg} \mathrm{~N} \mathrm{ha}^{-1}$ (P5), soil treatment, 20x10 $\mathrm{kg}$ cow manure ha- ${ }^{-1}, 136 \mathrm{~kg} \mathrm{~K} \mathrm{ha}^{-1}$ (P6). Furthermore, the lowest stolon length was found in soil treatment, without fertilizer (P0) of $34.13 \mathrm{~cm}$.

\section{Number of Leaves}

The results of the analysis of variance showed that the addition of organic and inorganic fertilizers had a significant effect on the number of leaves at the observation age $4,8,12,16,20,24$ and 32 DAP $(p<0.05)$. The average number of leaves is presented in Table 3 .

Based on the presentation of Table 3, the number of leaves at the observation age of 4 DAP, soil treatment, 20x $10^{3}$ $\mathrm{kg}$ of cow manure fertilizer ha ${ }^{-1}(\mathrm{P} 4)$ resulted in 3.44 more leaves compared to soil treatment, without fertilizer (P0), treatment soil, $138 \mathrm{~kg} \mathrm{~N}^{-1}(\mathrm{P} 1)$, soil treatment, $\mathrm{N}$ and $\mathrm{K}$, 138 and $136 \mathrm{~kg} \mathrm{ha}^{-1}(\mathrm{P} 3)$, and soil treatment, $20 \times 10^{3} \mathrm{~kg} \mathrm{cow}$ manure $\mathrm{ha}^{-1}, \mathrm{~N}$ and $\mathrm{K}, 138$ and $136 \mathrm{~kg} \mathrm{ha}^{-1}$ (P7), but not different from the number of leaves in soil treatment, $136 \mathrm{~kg}$ $\mathrm{K} \mathrm{ha}^{-1}(\mathrm{P} 2)$, soil treatment, $20 \times 10^{3} \mathrm{~kg}$ cow manure ha- ${ }^{-1}, 138$ $\mathrm{kg} \mathrm{N} \mathrm{ha}^{-1}$ (P5), and soil treatment, 20x10 $0^{3} \mathrm{~kg}$ of cow manure $\mathrm{ha}^{-1}, 136 \mathrm{~kg} \mathrm{~K} \mathrm{ha}^{-1}$ (P6). Furthermore, the lowest number of leaves is on the soil, without fertilizer (P0) of 1.22.

The number of leaves at the observation age of 8 DAP, soil treatment, $20 \times 10^{3} \mathrm{~kg}$ of cow manure ha- ${ }^{-1}(\mathrm{P} 4)$ produced 5.78 more leaves compared to soil treatment, without fertilizer (P0), soil treatment, $136 \mathrm{~kg} \mathrm{~K} \mathrm{ha}^{-1}$ ( $\mathrm{P} 2$ ), soil treatment, $\mathrm{N}$ and $\mathrm{K}, 138$ and $136 \mathrm{~kg} \mathrm{ha}^{-1}(\mathrm{P} 3)$, soil treatment, $20 \times 10^{3} \mathrm{~kg}$ of cow manure ha ${ }^{-1}, 136 \mathrm{~kg} \mathrm{~K}^{-1}$ (P6) and soil treatment, $20 \times 10^{3} \mathrm{~kg}$ of manure cows ha- ${ }^{-1}, \mathrm{~N}$ and $\mathrm{K}, 138$ and $136 \mathrm{~kg} \mathrm{ha}^{-1}(\mathrm{P} 7)$, but not different from the number of leaves in soil treatment, 138 $\mathrm{kg} \mathrm{N} \mathrm{ha}^{-1}(\mathrm{P} 1)$, and soil treatment, $20 \times 10^{3} \mathrm{~kg}$ of cow manure $\mathrm{ha}^{-1}, 138 \mathrm{~kg} \mathrm{~N} \mathrm{ha}^{-1}$ (P5). Furthermore, the lowest number of leaves is in the soil, without fertilizer (P0) of 2.78.

The number of leaves at the observation age of 12 DAP, soil treatment, $20 \times 10^{3} \mathrm{~kg}$ of cow manure ha ${ }^{-1}(\mathrm{P} 4)$ produced 11.78 more leaves compared to soil treatment, without fertilizer (P0), soil treatment, $138 \mathrm{~kg} \mathrm{~N} \mathrm{ha}^{-1}$ ( P1), soil treatment, $136 \mathrm{~kg} \mathrm{~K} \mathrm{ha}^{-1}(\mathrm{P} 2)$, soil treatment, $\mathrm{N}$ and $\mathrm{K}, 138$ and $136 \mathrm{~kg} \mathrm{ha}^{-1}(\mathrm{P} 3)$, but not different from the number of leaves in soil treatment, $20 \times 10^{3} \mathrm{~kg}$ of cow manure ha-1, 138 $\mathrm{kg} \mathrm{N} \mathrm{ha}^{-1}$ (P5), soil treatment, 20x10 $0^{3} \mathrm{~kg}$ cow manure ha- ${ }^{-1}$, $136 \mathrm{~kg} \mathrm{~K} \mathrm{ha}^{-1}$ (P6) and soil treatment, $20 \times 10^{3} \mathrm{~kg}$ cow manure $\mathrm{ha}^{-1}, \mathrm{~N}$ and $\mathrm{K}, 138$ and $136 \mathrm{~kg} \mathrm{ha}^{-1}$ (P7), then the lowest number of leaves was found in the soil, without fertilizer (P0) of 2.78 .
The number of leaves at the observation age of 16 DAP, soil treatment, $20 \times 10^{3} \mathrm{~kg}$ of cow manure ha-1 (P4) produced 29.22 more leaves compared to soil treatment, without fertilizer (P0), soil treatment, $138 \mathrm{~kg} \mathrm{~N} \mathrm{ha}^{-1}$ ( P1), soil treatment, $136 \mathrm{~kg} \mathrm{~K}^{-1}(\mathrm{P} 2)$, soil treatment, $20 \times 10^{3} \mathrm{~kg}$ of cow manure ha-1, $136 \mathrm{~kg} \mathrm{~K}^{-1}$ (P6) and soil treatment, $20 \times 10^{3} \mathrm{~kg}$ of cow manure ha- ${ }^{-1}, \mathrm{~N}$ and $\mathrm{K}, 138$ and $136 \mathrm{~kg} \mathrm{ha}^{-1}$ (P7), but not different from the number of leaves in the soil treatment, $\mathrm{N}$ and $\mathrm{K}, 138$ and $136 \mathrm{~kg} \mathrm{ha}^{-1}(\mathrm{P} 3)$, and soil, 20x10 $\mathrm{kg}$ of cow manure ha- ${ }^{-1}, 138 \mathrm{~kg} \mathrm{~N} \mathrm{ha}^{-1}$ (P5), then the lowest number of leaves was found in soil treatment, $20 \times 10^{3} \mathrm{~kg}$ of cow manure ha- ${ }^{-1}, \mathrm{~N}$ and $\mathrm{K}, 138$ and $136 \mathrm{~kg} \mathrm{ha}^{-1}(\mathrm{P} 7)$ of 13.89 .

The number of leaves at the observation age of 20 DAP, soil treatment, $20 \times 10^{3} \mathrm{~kg}$ of cow manure $\mathrm{ha}^{-1}(\mathrm{P} 4)$ produced 64.89 more leaves compared to other treatments, but did not differ from the number of leaves in soil treatment, $138 \mathrm{~kg} \mathrm{~N}$ $\mathrm{ha}^{-1}(\mathrm{P} 1)$. Furthermore, the lowest number of leaves was found in soil treatment, $136 \mathrm{~kg} \mathrm{~K} \mathrm{ha}^{-1}(\mathrm{P} 2)$ of 26.44 .

The number of leaves at the observation age of 24 DAP, soil treatment, $20 \times 10^{3} \mathrm{~kg}$ of cow manure ha ${ }^{-1}(\mathrm{P} 4)$ produced more leaves of 5.78 compared to soil treatment, $136 \mathrm{~kg} \mathrm{~K} \mathrm{ha}^{-1}$ (P2), soil treatment, $\mathrm{N}$ and $\mathrm{K}, 138$ and $136 \mathrm{~kg} \mathrm{ha}^{-1}$ (P3), soil treatment, $20 \times 10^{3} \mathrm{~kg}$ cow manure ha- ${ }^{-1}, 136 \mathrm{~kg} \mathrm{~K} \mathrm{ha}^{-1}$ (P6) and soil treatment, $20 \times 10^{3} \mathrm{~kg}$ cow manure ha ${ }^{-1}, \mathrm{~N}$ and $\mathrm{K}, 138$ and $136 \mathrm{~kg} \mathrm{ha}^{-1}$ (P7), but not different from the number of leaves without fertilizer (P0), soil treatment, $138 \mathrm{~kg} \mathrm{~N} \mathrm{ha}^{-1}(\mathrm{P} 1)$, and soil treatment, $20 \times 10^{3} \mathrm{~kg}$ cow manure $\mathrm{ha}^{-1}, 138 \mathrm{~kg} \mathrm{~N} \mathrm{ha}^{-1}$ (P5). Furthermore, the lowest number of leaves was found in soil treatment, $20 \times 10^{3} \mathrm{~kg}$ of cow manure ha- ${ }^{-1}, \mathrm{~N}$ and $\mathrm{K}, 138$ and $136 \mathrm{~kg} \mathrm{ha}^{-1}(\mathrm{P} 7)$ of 40.33 .

The number of leaves at the observation age of 28 DAP, soil treatment, $20 \times 10^{3} \mathrm{~kg}$ of cow manure ha $\mathrm{h}^{-1}(\mathrm{P} 4)$ produced more leaves of 142.44 compared to soil treatment, without fertilizer (P0), soil treatment, $138 \mathrm{~kg} \mathrm{~N} \mathrm{ha}^{-1}$ ( $\mathrm{P} 1$ ), on soil treatment, $136 \mathrm{~kg} \mathrm{~K} \mathrm{ha}^{-1}(\mathrm{P} 2)$, soil treatment, $\mathrm{N}$ and $\mathrm{K}, 138$ and $136 \mathrm{~kg} \mathrm{ha}^{-1}(\mathrm{P} 3)$, and soil treatment, $20 \times 10^{3} \mathrm{~kg}$ of cow manure $\mathrm{ha}^{-1}, \mathrm{~N}$ and $\mathrm{K}, 138$ and $136 \mathrm{~kg} \mathrm{ha}^{-1}(\mathrm{P} 7)$, but not different from the number of leaves, soil treatment, $20 \times 10^{3} \mathrm{~kg}$ of cow manure ha-1, $138 \mathrm{~kg} \mathrm{~N} \mathrm{ha}^{-1}$ (P5), and soil treatment, $20 \times 10^{3} \mathrm{~kg}$ of manure cattle ha-1, $136 \mathrm{~kg} \mathrm{~K} \mathrm{ha}^{-1}$ (P6). Furthermore, the lowest number of leaves was found in soil treatment, $136 \mathrm{~kg} \mathrm{~K} \mathrm{ha}^{-1}$ (P2) of 47.44 .

The number of leaves at the observation age of 32 DAP, soil treatment, $20 \times 10^{3} \mathrm{~kg}$ of cow manure ha ${ }^{-1}(\mathrm{P} 4)$ resulted in 142.44 more leaves than the soil treatment, without fertilizer (P0), soil treatment, $138 \mathrm{~kg} \mathrm{~N} \mathrm{ha}^{-1}$ ( P1), on soil treatment, 136 $\mathrm{kg} \mathrm{K} \mathrm{ha}^{-1}(\mathrm{P} 2)$, soil treatment, $\mathrm{N}$ and $\mathrm{K}, 138$ and $136 \mathrm{~kg} \mathrm{ha}^{-1}$ (P3), soil treatment, $20 \times 10^{3} \mathrm{~kg}$ cow manure ha ${ }^{-1}, 138 \mathrm{~kg} \mathrm{~N}^{-1} \mathrm{a}^{-}$ ${ }^{1}$ (P5), and soil treatment, 20x10 $0^{3} \mathrm{~kg}$ of cow manure $\mathrm{ha}^{-1}, \mathrm{~N}$ and $\mathrm{K}, 138$ and $136 \mathrm{~kg} \mathrm{ha}^{-1}$ (P7), but not different from the number of leaves in soil treatment, $20 \times 10^{3} \mathrm{~kg}$ of cow manure $\mathrm{ha}^{-1}, 136 \mathrm{~kg} \mathrm{~K} \mathrm{ha}^{-1}$ (P6). Furthermore, the lowest number of leaves was found in the soil, without fertilizer (P0) of 83.00.

\section{Leaf area}

The results of the analysis of variance showed that the addition of organic and inorganic fertilizers had a significant effect on leaf area at the ages of observation 4,8,12,16,20,24 and 32 DAP $(\mathrm{p}<0.05)$. The mean leaf area is presented in Table 4. 
Table 4, shows that at the age of 4 DAP observations, soil treatment, $\mathrm{N}$ and $\mathrm{K}, 138$ and $136 \mathrm{~kg} \mathrm{ha}^{-1}(\mathrm{P} 3)$, resulted in a leaf area of more than $13.41 \mathrm{~cm}^{2}$ compared to the leaf area in the treatment without fertilizer ( $\mathrm{P} 0)$, soil treatment, $20 \times 10^{3} \mathrm{~kg}$ of cow manure ha-1, $136 \mathrm{~kg} \mathrm{~K} \mathrm{ha}^{-1}(\mathrm{P} 6)$ and soil treatment, $20 \times 10^{3} \mathrm{~kg}$ of cow manure $\mathrm{ha}^{-1}, \mathrm{~N}$ and $\mathrm{K}, 138$ and $136 \mathrm{~kg} \mathrm{ha}^{-1}$ (P7), but not significantly different with the number of leaves in soil treatment, $138 \mathrm{~kg} \mathrm{~N} \mathrm{ha}^{-1}$ (P1), on soil treatment, $136 \mathrm{~kg}$ $\mathrm{K} \mathrm{ha}^{-1}(\mathrm{P} 2)$, treatment of $20 \times 10^{3} \mathrm{~kg}$ of cow manure ha ${ }^{-1}(\mathrm{P} 4)$, and soil treatment, $20 \times 10^{3} \mathrm{~kg}$ cow manure fertilizer ha- ${ }^{-1}, 138$ $\mathrm{kg} \mathrm{N} \mathrm{ha}^{-1}$ (P5). Furthermore, the smallest leaf area was found in soil treatment, $20 \times 10^{3} \mathrm{~kg}$ of cow manure $\mathrm{ha}^{-1}, \mathrm{~N}$ and $\mathrm{K}, 138$ and $136 \mathrm{~kg} \mathrm{ha}^{-1}$ (P7) of $7.91 \mathrm{~cm}^{2}$.

Leaf area at the observation ages of 8.24 , and 28 DAP, treatment of $20 \times 10^{3} \mathrm{~kg}$ of cow manure ha- ${ }^{-1}(\mathrm{P} 4)$, resulted in more leaf area of $33.57 \mathrm{~cm}^{2}, 564.04 \mathrm{~cm}^{2}$, and, respectively, $1210.61 \mathrm{~cm}^{2}$ compared to the leaf area in other treatments. Furthermore, the smallest leaf area at the observation age 8 and 28 DAP was found in the treatment without fertilizer (P0), respectively $13.99 \mathrm{~cm}^{2}$, and $268.70 \mathrm{~cm}^{2}$, while at the

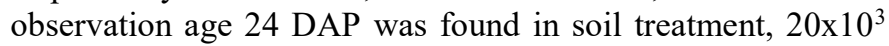
$\mathrm{kg}$ of cow manure ha- ${ }^{-1}, \mathrm{~N}$ and $\mathrm{K}, 138$ and $136 \mathrm{~kg} \mathrm{ha}^{-1}$ (P7) of $242.83 \mathrm{~cm}^{2}$, and

Leaf area at the age of observation 12 DAP, treatment $20 \times 10^{3} \mathrm{~kg}$ of cow manure $\mathrm{ha}^{-1}(\mathrm{P} 4)$, resulted in a leaf area of $53.64 \mathrm{~cm}^{2}$ more than the leaf area in the treatment without fertilizer (P0), in the soil treatment, $136 \mathrm{~kg} \mathrm{~K} \mathrm{ha}^{-1}$ ( P2), soil treatment, $\mathrm{N}$ and $\mathrm{K}, 138$ and $136 \mathrm{~kg} \mathrm{ha}^{-1}(\mathrm{P} 3)$, and soil treatment, $20 \times 10^{3} \mathrm{~kg}$ of cow manure ha- ${ }^{-1}, 136 \mathrm{~kg} \mathrm{~K} \mathrm{ha}^{-1}(\mathrm{P} 6)$ and soil treatment, $20 \times 10^{3} \mathrm{~kg}$ of fertilizer cow manure ha ${ }^{-1}, \mathrm{~N}$ and $\mathrm{K}, 138$ and $136 \mathrm{~kg} \mathrm{ha}^{-1}$ (P7), but not significantly different from the number of leaves in soil treatment, $20 \times 10^{3} \mathrm{~kg}$ of cow manure ha ${ }^{-1}, 138 \mathrm{~kg} \mathrm{~N} \mathrm{ha}^{-1}$ (P5). Furthermore, the smallest leaf area was found in soil treatment, $\mathrm{N}$ and $\mathrm{K}, 138$ and $136 \mathrm{~kg} \mathrm{ha}^{-1}$ (P3) of $24.21 \mathrm{~cm}^{2}$

Leaf area at the age of 16 DAP observations, treatment of $20 \times 10^{3} \mathrm{~kg}$ of cow manure $\mathrm{ha}^{-1}(\mathrm{P} 4)$, resulted in more leaf area of $132.95 \mathrm{~cm}^{2}$ compared to soil treatment, without fertilizer (P0), soil treatment, $138 \mathrm{~kg} \mathrm{~N}^{-1}(\mathrm{P} 1)$, on soil treatment, 136 $\mathrm{kg} \mathrm{K} \mathrm{ha}^{-1}(\mathrm{P} 2)$, soil treatment, $\mathrm{N}$ and $\mathrm{K}, 138$ and $136 \mathrm{~kg} \mathrm{ha}^{-1}$

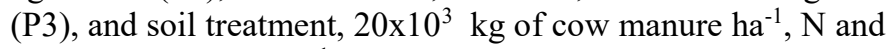
$\mathrm{K}, 138$ and $136 \mathrm{~kg} \mathrm{ha}^{-1}(\mathrm{P} 7)$, but not different from the number of leaves in soil treatment, $20 \times 10^{3} \mathrm{~kg}$ of cow manure ha- ${ }^{-1}, 138$ $\mathrm{kg} \mathrm{N} \mathrm{ha}^{-1}(\mathrm{P} 5)$, and soil treatment, $20 \times 10^{3} \mathrm{~kg}$ of cow manure. $\mathrm{ha}^{-1}, 136 \mathrm{~kg} \mathrm{~K} \mathrm{ha}^{-1}$ (P6). Furthermore, the smallest leaf area was found in the treatment without fertilizer (P0) of $57.25 \mathrm{~cm}^{2}$

Leaf area at the observation age of 20 DAP, treatment of $20 \times 10^{3} \mathrm{~kg}$ of cow manure $\mathrm{ha}^{-1}(\mathrm{P} 4)$, resulted in a leaf area of more than $314.95 \mathrm{~cm}^{2}$ compared to soil treatment, without fertilizer (P0), soil treatment, $138 \mathrm{~kg} \mathrm{~N} \mathrm{ha}^{-1}$ (P1), on soil treatment, $136 \mathrm{~kg} \mathrm{~K} \mathrm{ha}^{-1}(\mathrm{P} 2)$, and soil treatment, $20 \times 10^{3} \mathrm{~kg}$ of cow manure ha- ${ }^{-1}, \mathrm{~N}$ and $\mathrm{K}, 138$ and $136 \mathrm{~kg} \mathrm{ha}^{-1}(\mathrm{P} 7)$, but not different from the number of leaves on soil treatment, $\mathrm{N}$ and $\mathrm{K}, 138$ and $136 \mathrm{~kg} \mathrm{ha}^{-1}(\mathrm{P} 3)$, soil treatment, $20 \times 10^{3} \mathrm{~kg}$ cow manure ha-1, $138 \mathrm{~kg} \mathrm{~N}^{-1} \mathrm{ha}^{-1}$ (P5), and soil treatment, $20 \times 10^{3} \mathrm{~kg}$ cow manure ha- ${ }^{-1}, 136 \mathrm{~kg} \mathrm{~K} \mathrm{ha}^{-1}$ (P6). Furthermore, the smallest leaf area was found in the treatment without fertilizer (P0) of $117.78 \mathrm{~cm}^{2}$

Leaf area at the age of observation 32 DAP, treatment $20 \times 10^{3} \mathrm{~kg}$ of cow manure fertilizer ha- $\mathrm{a}^{-1}(\mathrm{P} 4)$, resulting in more leaf area of $1379.28 \mathrm{~cm}^{2}$ compared to leaf area in the treatment without fertilizer (P0), soil treatment, $\mathrm{N}$ and $\mathrm{K}, 138$ and $136 \mathrm{~kg} \mathrm{ha}^{-1}(\mathrm{P} 3)$, and soil treatment, $20 \times 10^{3} \mathrm{~kg}$ of cow manure ha ${ }^{-1}, \mathrm{~N}$ and $\mathrm{K}, 138$ and $136 \mathrm{~kg} \mathrm{ha}^{-1}(\mathrm{P} 7)$, but not significantly different from the number of leaves on), soil treatment, $138 \mathrm{~kg} \mathrm{~N} h a^{-1}(\mathrm{P} 1)$, on soil treatment, $136 \mathrm{~kg} \mathrm{~K}^{-1}$ (P2), soil treatment, 20x103 kg of cow manure ha- ${ }^{-1}, 138 \mathrm{~kg} \mathrm{~N}$ $\mathrm{ha}^{-1}$ (P5) and soil treatment, $20 \times 10^{3} \mathrm{~kg}$ of fertilizer cow manure ha ${ }^{-1}, 136 \mathrm{~kg} \mathrm{~K} \mathrm{ha}^{-1}$ (P6). Furthermore, the smallest leaf area was found in soil treatment, $\mathrm{N}$ and $\mathrm{K}, 138$ and $136 \mathrm{~kg}$ $\mathrm{ha}^{-1}(\mathrm{P} 3)$ of $467.17 \mathrm{~cm}^{2}$.

\section{Root Length}

The results of the analysis of variance showed that the addition of organic and inorganic fertilizers had a significant effect on root length at the observation ages of 4,8,12,16,20,24 and 32 DAP $(p<0.05)$. The average root length is presented in Table 5.

Table 5 , shows that at the age of observation 4,8 , and 12 DAP soil treatment, $20 \times 10^{3} \mathrm{~kg}$ of cow manure $\mathrm{ha}^{-1}(\mathrm{P} 4)$, produced longer roots of $8.65 \mathrm{~cm}, 9.67 \mathrm{~cm}$, and $10.03 \mathrm{~cm}$, respectively compared to the root length. In soil treatment, without fertilizer (P0), soil treatment, $138 \mathrm{~kg} \mathrm{~N}^{-1}$ (P1), soil treatment, $136 \mathrm{~kg} \mathrm{~K} \mathrm{ha}^{-1}(\mathrm{P} 2)$, soil treatment, $\mathrm{N}$ and $\mathrm{K}, 138$ and $136 \mathrm{~kg} \mathrm{ha}^{-1}(\mathrm{P} 3)$, soil treatment, $20 \times 10^{3} \mathrm{~kg}$ cow manure $\mathrm{ha}^{-1}, 138 \mathrm{~kg} \mathrm{~N}^{-1}$ (P5), and soil treatment, 20x10 $\mathrm{kg}^{3}$ cow manure ha ${ }^{-1}, \mathrm{~N}$ and $\mathrm{K}, 138$ and $136 \mathrm{~kg} \mathrm{ha}^{-1}(\mathrm{P} 7)$, but not significantly different from soil treatment, $20 \times 10^{3} \mathrm{~kg}$ of cow manure ha ${ }^{-1}, 136 \mathrm{~kg} \mathrm{~K} \mathrm{ha}^{-1}$ (P6). On observations 4, 8, and 12 DAP, the most minor root lengths were found in soil treatment, without fertilizer (P0), respectively $6.02 \mathrm{~cm}, 6.44$ $\mathrm{cm}$, and $7.07 \mathrm{~cm}$.

The root length of the observation age 16, 20, 24, and 28 DAP soil treatment, $20 \times 10^{3} \mathrm{~kg}$ of cow manure $\mathrm{ha}^{-1}(\mathrm{P} 4)$, resulted in longer roots of $11.78 \mathrm{~cm}, 17.19 \mathrm{~cm}, 22.32 \mathrm{~cm}$, and $20.68 \mathrm{~cm}$, respectively compared to the length roots in other treatments. On observations 16,24 , and $28 \mathrm{DAP}$, the minor root lengths were found in soil treatment, without fertilizer (P0), respectively $6.02 \mathrm{~cm}, 6.44 \mathrm{~cm}$, and $7.07 \mathrm{~cm}$. The smallest root length at the observation age of 16 DAP was found in soil treatment, without fertilizer $(\mathrm{P} 0)$ of $7.31 \mathrm{~cm}$, observation age of $20 \mathrm{DAP}$, at $20 \times 10^{3} \mathrm{~kg}$ of cow manure ha ${ }^{-1}$, $\mathrm{N}$ and $\mathrm{K}, 138$ and $136 \mathrm{~kg} \mathrm{ha}^{-1}$ ( P7) of $10.03 \mathrm{~cm}$. The age of observation of 24 DAP was found in soil treatment, without fertilizer (P0) of $12.57 \mathrm{~cm}$, and the period of observation of 28 DAP was found in soil treatment, $\mathrm{N}$ and $\mathrm{K}, 138$ and $136 \mathrm{~kg}^{-} \mathrm{ha}^{-}$ ${ }^{1}(\mathrm{P} 3)$ of $12.56 \mathrm{~cm}$.

The root length of the observation age 32 DAP, soil treatment, $20 \times 10^{3} \mathrm{~kg}$ of cow manure ha-1 $(\mathrm{P} 4)$ produced $23.85 \mathrm{~cm}$ longer roots compared to the root length in soil treatment, $138 \mathrm{~kg} \mathrm{~N}$ $\mathrm{ha}^{-1}$ (P1), soil treatment, $\mathrm{N}$ and $\mathrm{K}, 138$ and $136 \mathrm{~kg} \mathrm{ha}^{-1}$ (P3),

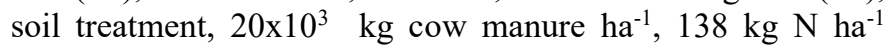
(P5), soil treatment, $20 \times 10^{3} \mathrm{~kg}$ cow manure $\mathrm{ha}^{-1}, 136 \mathrm{~kg} \mathrm{~K}^{-}$ ${ }^{1}$ (P6) and treatment $20 \times 10^{3} \mathrm{~kg}$ of cow manure ha ${ }^{-1}, \mathrm{~N}$ and $\mathrm{K}$, 138 and $136 \mathrm{~kg} \mathrm{ha}^{-1}(\mathrm{P} 7)$, but not significantly different from soil treatment, without fertilizer (P0), and treatment soil, 136 $\mathrm{kg} \mathrm{K} \mathrm{ha}{ }^{-1}$ (P2). Furthermore, the smallest root length was found in soil treatment, $138 \mathrm{~kg} \mathrm{~N}^{-1}(\mathrm{P} 1)$ of $13.89 \mathrm{~cm}$. The research findings showed that the root length increased from 4 DAP to 32 DAP observations. 


\section{Stomata density}

The results of the analysis of variance showed that the addition of organic and inorganic fertilizers had a significant effect on the number, width, and length of the stomata ( $p$ $<0.05$ ). The mean stomata are presented in Table 6 .

Observation of the number of stomata in Table 6 shows that soil treatment, $20 \times 10^{3} \mathrm{~kg}$ of cow manure $\mathrm{ha}^{-1}(\mathrm{P} 4)$, produces a higher number of stomata by $13.25 \mathrm{~cm}$ compared to the number of stomata in soil treatment, without fertilizer $(\mathrm{P} 0)$, soil treatment, $138 \mathrm{~kg} \mathrm{~N}^{-1}(\mathrm{P} 1)$, soil treatment, $136 \mathrm{~kg}$ $\mathrm{K} \mathrm{ha}^{-1}(\mathrm{P} 2)$, soil treatment, $20 \times 103 \mathrm{~kg}$ of cow manure ha ${ }^{-1}, 136$ $\mathrm{kg} \mathrm{K} \mathrm{ha}{ }^{-1}(\mathrm{P} 6)$ and $20 \times 10^{3} \mathrm{~kg}$ of cow manure ha ${ }^{-1}, \mathrm{~N}$ and $\mathrm{K}$, 138 and $136 \mathrm{~kg} \mathrm{ha}^{-1}(\mathrm{P} 7)$, but not significantly different from soil treatment, $\mathrm{N}$ and $\mathrm{K}, 138$ and $136 \mathrm{~kg} \mathrm{ha}^{-1}$ (P3), and soil treatment, $20 \times 10^{3} \mathrm{~kg}$ of cow manure fertilizer ha ${ }^{-1}, 138 \mathrm{~kg} \mathrm{~N}$ $\mathrm{ha}^{-1}$ (P5), the least number of stomata was found in the treatment without fertilizer (P0) of $8.08 \mathrm{~cm}$. Furthermore, soil treatment, $20 \times 10^{3} \mathrm{~kg}$ of cow manure ha ${ }^{-1}(\mathrm{P} 4)$ produced the widest stomata of $10.87 \mathrm{~cm}$ compared to the treatment without fertilizer (P0), soil treatment, $138 \mathrm{~kg} \mathrm{~N} \mathrm{ha}^{-1}(\mathrm{P} 1)$, soil treatment, $20 \times 10^{3} \mathrm{~kg}$ of fertilizer cow manure $\mathrm{ha}^{-1}, 136 \mathrm{~kg} \mathrm{~K}$ $\mathrm{ha}^{-1}$ (P6) and treatment $20 \times 10^{3} \mathrm{~kg}$ of cow manure $\mathrm{ha}^{-1}, \mathrm{~N}$ and $\mathrm{K}, 138$ and $136 \mathrm{~kg} \mathrm{ha}^{-1}(\mathrm{P} 7)$, but not significantly different from soil treatment, $136 \mathrm{~kg} \mathrm{~K}^{-1}(\mathrm{P} 2)$, soil treatment, $\mathrm{N}$ and $\mathrm{K}, 138$ and $136 \mathrm{~kg} \mathrm{ha}^{-1}(\mathrm{P} 3)$, and soil treatment, $20 \times 10^{3} \mathrm{~kg}$ of cow manure $\mathrm{ha}^{-1}, 138 \mathrm{~kg} \mathrm{~N}^{-1}(\mathrm{P} 5)$, treatment without fertilizer (P0) resulted in stomata less wide by $6.31 \mathrm{~cm}$.

Density according to the length of stomata, soil treatment, $20 \times 10^{3} \mathrm{~kg}$ of cow manure ha ${ }^{-1}(\mathrm{P} 4)$ produced the longest stomata of $19.76 \mathrm{~cm}$ compared to the size of stomata in the treatment without fertilizer (P0), soil treatment, $138 \mathrm{~kg} \mathrm{~N}^{-}$ ${ }^{1}(\mathrm{P} 1)$, soil treatment, $20 \times 103 \mathrm{~kg}$ of cow manure $\mathrm{ha}^{-1}, 136 \mathrm{~kg} \mathrm{~K}$ ha-1 (P6) and $20 \times 10^{3} \mathrm{~kg}$ of cow manure ha- ${ }^{-1}, \mathrm{~N}$ and $\mathrm{K}, 138$ and $136 \mathrm{~kg} \mathrm{ha}^{-1}(\mathrm{P} 7)$ but not different real with soil treatment, $136 \mathrm{~kg} \mathrm{~K} \mathrm{ha}^{-1}(\mathrm{P} 2)$, soil treatment, $\mathrm{N}$ and $\mathrm{K}, 138$ and $136 \mathrm{~kg} \mathrm{ha}^{-}$ ${ }^{1}(\mathrm{P} 3)$, and soil treatment, $20 \times 10^{3} \mathrm{~kg}$ of cow manure ha ${ }^{-1}, 138$ $\mathrm{kg} \mathrm{N}$ ha $^{-1}(\mathrm{P} 5)$, treatment without fertilizer (P0) resulted in stomata less wide by $12.39 \mathrm{~cm}$.

\section{Response of organic and inorganic fertilizers to the Yield Components \\ Leaf fresh weight}

The results of the analysis of variance showed that the addition of organic and inorganic fertilizers had a significant effect on leaf fresh weight at the observation ages of $4,8,12,16,20,24$ and 32 DAP $(p<0.05)$. The average leaf fresh weight is presented in Table 7 .

Based on Table 7, it shows that the age of observation 4 DAP, soil treatment, $20 \times 10^{3} \mathrm{~kg}$ of cow manure fertilizer ha${ }^{1}(\mathrm{P} 4)$ produces fresh leaf weight that is heavier by $0.133 \mathrm{~g}$ compared to fresh leaf weight in soil treatment, without fertilizer (P0), treatment soil, $138 \mathrm{~kg} \mathrm{~N}^{-1}(\mathrm{P} 1)$, soil treatment, 20x10 $0^{3} \mathrm{~kg}$ cow manure $\mathrm{ha}^{-1}, 136 \mathrm{~kg} \mathrm{~K} \mathrm{ha}^{-1}(\mathrm{P} 6)$ and 20x10 $0^{3}$ cow manure ha- ${ }^{-1}, \mathrm{~N}$ and $\mathrm{K}, 138$ and $136 \mathrm{~kg} \mathrm{ha}^{-1}$ (P7), but not significantly different from soil needs, $136 \mathrm{~kg} \mathrm{~K}$ $\mathrm{ha}^{-1}(\mathrm{P} 2)$, soil treatment, $\mathrm{N}$ and $\mathrm{K}, 138$ and $136 \mathrm{~kg} \mathrm{ha}^{-1}(\mathrm{P} 3)$, and soil treatment, $20 \times 10^{3} \mathrm{~kg}$ of cow manure ha-1, $138 \mathrm{~kg} \mathrm{~N}$ $\mathrm{ha}^{-1}(\mathrm{P} 5)$. The smallest fresh weight was found in the treatment, without fertilizer (P0) of $0.047 \mathrm{~g}$.
Observation ages 8 and 12 DAP resulted in heavier leaf fresh weight in soil treatment, $20 \times 10^{3} \mathrm{~kg}$ of cow manure ha ${ }^{-1}(\mathrm{P} 4)$, respectively $0.276 \mathrm{~g}$ and $0.514 \mathrm{~g}$ but not significantly different from leaf fresh weight in soil treatment. $20 \times 10^{3} \mathrm{~kg}$ of cow manure $\mathrm{ha}^{-1}, 138 \mathrm{~kg} \mathrm{~N}^{-1}(\mathrm{P} 5)$. The lowest fresh leaf weight was found in the treatment without fertilizer (P0) of $0.123 \mathrm{~g}$ and $0.167 \mathrm{~g}$, respectively.

Leaf fresh weight at the age of 16 DAP observations, soil treatment, $20 \times 10^{3} \mathrm{~kg}$ of cow manure fertilizer ha-1 $(\mathrm{P} 4)$ resulted in leaf fresh weight weighing $1.464 \mathrm{~g}$ compared to leaf fresh weight in other treatments. The smallest fresh leaf weight was found in soil treatment, $20 \times 10^{3} \mathrm{~kg}$ of cow manure ha ${ }^{-1}, \mathrm{~N}$ and $\mathrm{K}, 138$ and $136 \mathrm{~kg}$ ha ha ${ }^{-1}(\mathrm{P} 7)$ of $0.512 \mathrm{~g}$.

Leaf fresh weight at the observation age of 20 DAP soil treatment, $20 \times 10^{3} \mathrm{~kg}$ of cow manure $\mathrm{ha}^{-1}(\mathrm{P} 4)$ is more weight of 2,788 $\mathrm{g}$ compared to leaf fresh weight in soil treatment, without fertilizer ( $\mathrm{P} 0)$, soil treatment, $138 \mathrm{~kg} \mathrm{~N}^{-1}(\mathrm{P} 1)$, soil treatment, $136 \mathrm{~kg} \mathrm{~K} \mathrm{ha}^{-1}(\mathrm{P} 2)$, soil treatment, $\mathrm{N}$ and $\mathrm{K}, 138$ and $136 \mathrm{~kg} \mathrm{ha}^{-1}(\mathrm{P} 3)$, and soil treatment, $20 \times 10^{3} \mathrm{~kg}$ of cow manure $\mathrm{ha}^{-1}, \mathrm{~N}$ and $\mathrm{K}, 138$ and $136 \mathrm{~kg} \mathrm{ha}^{-1}(\mathrm{P} 7)$, but not significantly different from soil treatment, $20 \times 10^{3} \mathrm{~kg}$ of cow manure ha ${ }^{-1}$, $138 \mathrm{~kg} \mathrm{~N} \mathrm{ha}^{-1}(\mathrm{P} 5)$ and soil treatment, $20 \times 10^{3} \mathrm{~kg}$ of cow manure ha-1 $136 \mathrm{~kg} \mathrm{~K} \mathrm{ha}^{-1}(\mathrm{P} 6)$. The smallest fresh leaf weight was found in soil treatment, $138 \mathrm{~kg} \mathrm{~N} \mathrm{ha}^{-1}(\mathrm{P} 1)$ of $1,234 \mathrm{~g}$.

Leaf fresh weight at the observation age of 24 DAP resulted in a heavier leaf fresh weight in soil treatment, $20 \times 10^{3}$ $\mathrm{kg}$ of cow manure ha ${ }^{-1}(\mathrm{P} 4)$ of $4.974 \mathrm{gr}$ but not significantly different soil treatment $20 \times 10^{3} \mathrm{~kg}$ of cow manure ha-1, $138 \mathrm{~kg}$ $\mathrm{N}$ ha ${ }^{-1}(\mathrm{P} 5)$. The lowest fresh leaf weight was found in the treatment without fertilizer (P0) of $1.882 \mathrm{~g}$.

Fresh leaf weight at the age of 28 and 32 DAP observations, in soil treatment, $20 \times 10^{3} \mathrm{~kg}$ of cow manure fertilizer ha ${ }^{-1}(\mathrm{P} 4)$ is heavier, respectively $5,642 \mathrm{~g}$ and $12,907 \mathrm{~g}$ compared to other treatments. The smallest fresh leaf weight was found without fertilizer (P0), respectively $2.237 \mathrm{~g}$ and $6.036 \mathrm{~g}$.

\section{Leaf Dry Weight}

The results of the analysis of variance showed that the addition of organic and inorganic fertilizers had a significant effect on leaf dry weight at the observation ages of $4,8,12,16,20,24$ and 32 DAP $(p<0.05)$. The average leaf dry weight is presented in Table 8 .

Based on Table 8 , it shows that at the age of 4 DAP observations on soil treatment, $20 \times 10^{3} \mathrm{~kg}$ of cow manure fertilizer ha ${ }^{-1}(\mathrm{P} 4)$ produces leaf dry weight that is heavier by $0.047 \mathrm{~g}$ compared to dry leaf weight in other treatments but not significantly different from soil treatment, $20 \times 10^{3} \mathrm{~kg}$ of cow manure ha ${ }^{-1}, 138 \mathrm{~kg} \mathrm{~N}^{-1}(\mathrm{P} 5)$. The smallest leaf dry weight was found in the treatment without fertilizer ( $\mathrm{P} 0)$ of $0.015 \mathrm{~g}$.

Leaf dry weight at the age of 8 DAP observations resulted in heavier leaf dry weight in soil treatment, $20 \times 10^{3} \mathrm{~kg}$ of cow manure $\mathrm{ha}^{-1}(\mathrm{P} 4)$ of $0.198 \mathrm{~g}$ compared to dry leaf weight in other treatments, then the smallest leaf dry weight was found in the treatment. Without fertilizer (P0) of $0.022 \mathrm{~g}$.

Leaf dry weight at the observation age of 12 DAP resulted in a heavier leaf dry weight in soil treatment, $20 \times 10^{3} \mathrm{~kg}$ of cow manure ha ${ }^{-1}(\mathrm{P} 4)$ of $0.183 \mathrm{~g}$ compared to leaf dry weight in the treatment without fertilizer (P0), soil treatment, $138 \mathrm{~kg}$ $\mathrm{N} \mathrm{ha}^{-1}(\mathrm{P} 1)$, soil treatment, $136 \mathrm{~kg} \mathrm{~K} \mathrm{ha}^{-1}(\mathrm{P} 2)$, soil treatment, 
$20 \times 10^{3} \mathrm{~kg}$ of cow manure $\mathrm{ha}^{-1}, 136 \mathrm{~kg} \mathrm{~K} \mathrm{ha}^{-1}(\mathrm{P} 6)$ and $20 \times 10^{3}$ $\mathrm{kg}$ of cow manure ha- ${ }^{-1}, \mathrm{~N}$ and $\mathrm{K}, 138$ and $136 \mathrm{~kg} \mathrm{ha}^{-1}(\mathrm{P} 7)$, but not significantly different from soil treatment, $\mathrm{N}$ and $\mathrm{K}, 138$ and $136 \mathrm{~kg} \mathrm{ha}^{-1}(\mathrm{P} 3)$, and soil treatment $20 \times 10^{3} \mathrm{~kg}$ of cow manure ha ${ }^{-1}, 138 \mathrm{~kg} \mathrm{~N} \mathrm{ha}^{-1}(\mathrm{P} 5)$. The smallest leaf dry weight was found in the treatment without fertilizer (P0) of $0.030 \mathrm{~g}$.

Leaf dry weight at the observation age of 16 DAP in soil treatment, $20 \times 10^{3} \mathrm{~kg}$ of cow manure ha $\mathrm{a}^{-1}(\mathrm{P} 4)$ resulted in leaf dry weight that was heavier by $0.216 \mathrm{~g}$ compared to leaf dry weight in other treatments but not significantly different from soil treatment, 20x103 kg cow manure fertilizer ha ${ }^{-1}, 138 \mathrm{~kg} \mathrm{~N}$ $\mathrm{ha}^{-1}(\mathrm{P} 5)$. The smallest leaf dry weight was found in the treatment without fertilizer (P0) of $0.082 \mathrm{~g}$.

Leaf dry weight at the observation age of 20 DAP resulted in a heavier leaf dry weight in soil treatment, $20 \times 10^{3} \mathrm{~kg}$ of cow manure ha ${ }^{-1}(\mathrm{P} 4)$ of $0.496 \mathrm{~g}$ compared to leaf dry weight in the treatment without fertilizer (P0), soil treatment, $138 \mathrm{~kg} \mathrm{~N} \mathrm{ha}^{-}$ ${ }^{1}(\mathrm{P} 1)$, soil treatment, $136 \mathrm{~kg} \mathrm{~K}$ ha-1 (P2), soil treatment, $\mathrm{N}$ and $\mathrm{K}, 138$ and $136 \mathrm{~kg} \mathrm{ha}^{-1}(\mathrm{P} 3)$, and $20 \times 10^{3} \mathrm{~kg}$ of manure fertilizer cows ha ${ }^{-1}, \mathrm{~N}$ and $\mathrm{K}, 138$ and $136 \mathrm{~kg} \mathrm{ha}^{-1}(\mathrm{P} 7)$, but not significantly different from soil treatment, $20 \times 10^{3} \mathrm{~kg}$ of cow

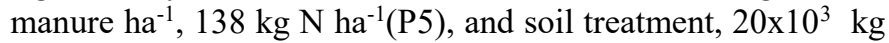
of cow manure ha ${ }^{-1}, 136 \mathrm{~kg} \mathrm{~K} \mathrm{ha}^{-1}(\mathrm{P} 6)$. The smallest leaf dry weight was found in the treatment without fertilizer (P0) of $0.185 \mathrm{~g}$.

Leaf dry weight at the observation age of 24 and 28 DAP resulted in heavier leaf dry weight in soil treatment, $20 \times 103 \mathrm{~kg}$ of cow manure ha ${ }^{-1}(\mathrm{P} 4)$ of $0.866 \mathrm{~g}$ and $1.442 \mathrm{~g}$ respectively compared to dry leaf weight in other treatments, then The smallest leaf dry weight was found in the treatment without fertilizer (P0) of $0.380 \mathrm{~g}$ and $0.437 \mathrm{~g}$, respectively.

Leaf dry weight observed at 32 DAP in soil treatment, $20 \times 10^{3} \mathrm{~kg}$ of cow manure ha- ${ }^{-1}(\mathrm{P} 4)$ resulted in leaf dry weight that was heavier by $1.802 \mathrm{~g}$ compared to dry leaf weight in other treatments but not significantly different from soil treatment, $20 \times 10^{3} \mathrm{~kg}$ of fertilizer cow manure $\mathrm{ha}^{-1}, 138 \mathrm{~kg} \mathrm{~N}$ $\mathrm{ha}^{-1}(\mathrm{P} 5)$ and soil treatment, $136 \mathrm{~kg} \mathrm{~K} \mathrm{ha}^{-1}(\mathrm{P} 2)$. The smallest leaf dry weight was found in the treatment without fertilizer (P0) of $0.671 \mathrm{~g}$.

\section{Total Fresh Weight}

Variance analysis showed that the addition of organic and inorganic fertilizers had a significant effect on the total fresh weight at the observation age 4,8,12,16,20,24 and 32 DAP (p $<0.05$ ). The mean total fresh weight is presented in Table 9 .

Based on the presentation of Table 9 , it shows that at the age of $4,8.24$, and 28 DAP in soil treatment, $20 \times 10^{3} \mathrm{~kg}$ of cow manure ha ${ }^{-1}(\mathrm{P} 4)$ produces a total fresh weight that is heavier, respectively $0.643 \mathrm{~g}, 1.199 \mathrm{~g}, 17.221 \mathrm{~g}$, and $193,770 \mathrm{~g}$ compared to total fresh weight in other treatments. The smallest total fresh weight of observation age 4,8 , and 24 DAP was found in the treatment, without fertilizer (P0), respectively $0.280 \mathrm{~g}, 0.598 \mathrm{~g}$, and $7,288 \mathrm{~g}$. In contrast, at the observation age $28 \mathrm{DAP}$, soil treatment, $136 \mathrm{~kg} \mathrm{~K} \mathrm{ha}^{-1}(\mathrm{P} 2)$, produces the smallest total fresh weight of $75.011 \mathrm{~g}$.

Total fresh weight at the observation age of 12 DAP, soil treatment, $20 \times 10^{3} \mathrm{~kg}$ of cow manure $\mathrm{ha}^{-1}(\mathrm{P} 4)$ resulted in a total fresh weight that was heavier by $1,867 \mathrm{~g}$ compared to the total fresh weight in other treatments but not significantly different from soil treatment, $20 \times 10^{3} \mathrm{~kg}$ cow manure fertilizer $\mathrm{ha}^{-1}, 138 \mathrm{~kg} \mathrm{~N} \mathrm{ha}^{-1}(\mathrm{P} 5)$. The smallest total fresh weight is found in the treatment without fertilizer (P0) of $0.783 \mathrm{~g}$.

Total fresh weight at the observation age of 16 and 20 DAP produces the heaviest total fresh weight in soil treatment, $20 \times 10^{3} \mathrm{~kg}$ of cow manure ha ${ }^{-1}(\mathrm{P} 4)$ of 3,866 $\mathrm{g}$ and 9,396 $\mathrm{g}$ respectively compared to the total fresh weight in soil treatment, without fertilizer (P0), soil treatment, $138 \mathrm{~kg} \mathrm{~N}^{-}$ ${ }^{1}(\mathrm{P} 1)$, soil treatment, $136 \mathrm{~kg} \mathrm{~K} \mathrm{ha}^{-1}(\mathrm{P} 2)$, soil treatment, $\mathrm{N}$ and $\mathrm{K}, 138$ and $136 \mathrm{~kg} \mathrm{ha}^{-1}(\mathrm{P} 3)$, and soil treatment, $20 \times 10^{3} \mathrm{~kg}$ of cow manure ha ${ }^{-1}, \mathrm{~N}$ and $\mathrm{K}, 138$ and $136 \mathrm{~kg} \mathrm{ha}^{-1}(\mathrm{P} 7)$, but not significantly different from soil treatment, $20 \times 103 \mathrm{~kg}$ of cow manure ha- ${ }^{-1}, 138 \mathrm{~kg} \mathrm{~N} \mathrm{ha}^{-1}(\mathrm{P} 5)$ and soil treatment, $20 \times 103 \mathrm{~kg}$ of cow manure $\mathrm{ha}^{-1}, 136 \mathrm{~kg} \mathrm{~K} \mathrm{ha}^{-1}(\mathrm{P} 6)$. The smallest total fresh weight in the 16 DAP observations was found in the fertilizer-free treatment (P0) of 1,669 g, while in the 20 DAP observations, there were soil treatment treatments, $136 \mathrm{~kg} \mathrm{~K}$ $\mathrm{ha}^{-1}(\mathrm{P} 2)$ of $4.609 \mathrm{~g}$.

Total fresh weight at the observation age of 32 DAP, soil treatment, $20 \times 10^{3} \mathrm{~kg}$ of cow manure $\mathrm{ha}^{-1}(\mathrm{P} 4)$ produces a total fresh weight that is heavier of $210,830 \mathrm{~g}$ compared to the total fresh weight in soil treatment, without fertilizer (P0), soil treatment, $\mathrm{N}$ and $\mathrm{K}, 138$ and $136 \mathrm{~kg} \mathrm{ha}^{-1}(\mathrm{P} 3)$, and soil treatment, $20 \times 10^{3} \mathrm{~kg}$ of cow manure ha ${ }^{-1}, \mathrm{~N}$ and $\mathrm{K}, 138$ and $136 \mathrm{~kg} \mathrm{ha}^{-1}(\mathrm{P} 7)$, but not significantly different from soil treatment, $138 \mathrm{~kg} \mathrm{~N} \mathrm{ha}^{-1}(\mathrm{P} 1)$, soil treatment, $136 \mathrm{~kg} \mathrm{~K}^{-}$ ${ }^{1}(\mathrm{P} 2)$, soil treatment $20 \times 10^{3} \mathrm{~kg}$ cow manure $\mathrm{ha}^{-1}, 138 \mathrm{~kg} \mathrm{~N}^{-}$

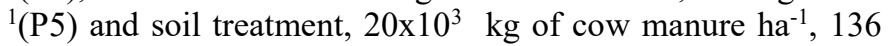
$\mathrm{kg} \mathrm{K} \mathrm{ha} \mathrm{a}^{-1}(\mathrm{P} 6)$. The smallest total fresh weight was found in soil treatment, $20 \times 10^{3} \mathrm{~kg}$ of cow manure $\mathrm{ha}^{-1}, \mathrm{~N}$ and $\mathrm{K}, 138$ and $136 \mathrm{~kg} \mathrm{ha}^{-1}(\mathrm{P} 7), 102,482 \mathrm{~g}$.

\section{Total Dry Weight}

The results of the analysis of variance showed that the addition of organic and inorganic fertilizers had a significant effect on the total dry weight at the observation age $4,8,12,16,20,24$ and 32 DAP ( $<<0.05$ ). The mean total dry weight is presented in Table 10.

Table 10 shows that at the age of observation 4 and 8 DAP, in soil treatment, $20 \times 10^{3} \mathrm{~kg}$ of cow manure ha ${ }^{-1}(\mathrm{P} 4)$ produces a total dry weight of $0.149 \mathrm{~g}$ and $0.206 \mathrm{~g}$, respectively compared to the total dry weight in the treatment without fertilizer (P0), soil treatment, $138 \mathrm{~kg} \mathrm{~N} \mathrm{ha}^{-1}(\mathrm{P} 1)$, soil treatment, $136 \mathrm{~kg} \mathrm{~K}^{-1}(\mathrm{P} 2)$, soil treatment, $20 \times 10^{3} \mathrm{~kg}$ of cow manure $\mathrm{ha}^{-1}, 136 \mathrm{~kg} \mathrm{~K} \mathrm{ha}^{-1}(\mathrm{P} 6)$ and soil treatment, $20 \times 10^{3} \mathrm{~kg}$ of cow manure $\mathrm{ha}^{-1}, \mathrm{~N}$ and $\mathrm{K}, 138$ and $136 \mathrm{~kg} \mathrm{ha}^{-1}(\mathrm{P} 7)$, but not significantly different from soil treatment, $\mathrm{N}$ and $\mathrm{K}, 138$ and $136 \mathrm{~kg} \mathrm{ha}^{-1}(\mathrm{P} 3)$, and soil treatment, $20 \times 10^{3} \mathrm{~kg}$ of cow manure $\mathrm{ha}^{-1}, 138 \mathrm{~kg} \mathrm{~N}^{-1}(\mathrm{P} 5)$. The smallest total dry weight was found in the treatment without fertilizer (P0) of $0.053 \mathrm{~g}$ and $0.087 \mathrm{~g}$, respectively.

Total dry weight at observation age 12 and 16 DAP, soil treatment, $20 \times 10^{3} \mathrm{~kg}$ of cow manure fertilizer ha ${ }^{-1}(\mathrm{P} 4)$ resulted in total dry weight of $0.485 \mathrm{~g}$ and $0.603 \mathrm{~g}$ respectively compared to total dry weight in other treatments, but not different. Accurate with total dry weight in soil treatment, $20 \times 10^{3} \mathrm{~kg}$ of cow manure $\mathrm{ha}^{-1}, 138 \mathrm{~kg} \mathrm{~N} \mathrm{ha}^{-1}$ (P5). The smallest total dry weight was found in the treatment without fertilizer (P0) of $0.117 \mathrm{~g}$ and $0.220 \mathrm{~g}$, respectively.

The total dry weight at the observation age of 20 DAP, soil treatment, $20 \times 10^{3} \mathrm{~kg}$ of cow manure ha ${ }^{-1}(\mathrm{P} 4)$ produced a 
total dry weight of $1,588 \mathrm{~g}$ compared to the total dry weight in other treatments. Still, it was not significantly different from the total dry weight in soil treatment, $20 \times 10^{3} \mathrm{~kg}$ of cow manure ha-1, $138 \mathrm{~kg} \mathrm{~N} \mathrm{ha}^{-1}(\mathrm{P} 5)$, and soil treatment, 20x10 ${ }^{3} \mathrm{~kg}$ of cow manure ha-1, $136 \mathrm{~kg} \mathrm{~K}^{-1}(\mathrm{P} 6)$. The most negligible total dry weight is found in the treatment without fertilizer (P0) of $0.473 \mathrm{~g}$.

Total dry weight at observation age of 24.28 and 32 DAP, in soil treatment, $20 \times 10^{3} \mathrm{~kg}$ of cow manure ha-1 $(\mathrm{P} 4)$ resulted in a total dry weight of $3.011 \mathrm{~g}, 4.829 \mathrm{~g}$, and $7.823 \mathrm{~g}$, respectively compared to the total dry weight. In other treatments, The smallest total dry weight was found in the treatment without fertilizer (P0) of $1.096 \mathrm{~g}, 1.562 \mathrm{~g}$, and 2.653 g, respectively.

\section{Harvest Fresh Weight}

The results of the analysis of variance showed that the addition of organic and inorganic fertilizers had a significant effect on the fresh weight of the harvest $(p<0.05)$. The average harvest fresh weight is presented in Table 11.

Based on the presentation of Table 11, the fresh weight of the leaves, roots, and total harvest in soil treatment, 20x103 kg of cow manure ha ${ }^{-1}(\mathrm{P} 4)$, is more than $64.19 \mathrm{~g}$ of leaf weight compared to soil treatment without fertilizer (P0), soil treatment, without fertilizer (P0), soil treatment, $138 \mathrm{~kg} \mathrm{~N} \mathrm{ha}^{-}$ ${ }^{1}(\mathrm{P} 1)$, soil treatment, $136 \mathrm{~kg} \mathrm{~K} \mathrm{ha}^{-1}(\mathrm{P} 2)$, soil treatment, $\mathrm{N}$ and $\mathrm{K}, 138$ and $136 \mathrm{~kg} \mathrm{ha}^{-1}(\mathrm{P} 3)$, and soil treatment, $20 \times 10^{3} \mathrm{~kg}$ of cow manure ha ${ }^{-1}, \mathrm{~N}$ and $\mathrm{K}, 138$ and $136 \mathrm{~kg} \mathrm{ha}^{-1}(\mathrm{P} 7)$, but not significantly different from soil treatment, $20 \times 10^{3} \mathrm{~kg}$ of cow manure ha ${ }^{-1}, 138 \mathrm{~kg} \mathrm{~N}^{-1}(\mathrm{P} 5)$ and soil treatment, 20x10 ${ }^{3} \mathrm{~kg}$ of cow manure ha-1, $136 \mathrm{~kg} \mathrm{~K} \mathrm{ha}^{-1}(\mathrm{P} 6)$. Furthermore, the smallest fresh weight on leaves is soil treatment, without fertilizer (P0) of $18.18 \mathrm{~g}$.

Furthermore, the fresh harvest weight of the stalk of soil treatment, $20 \times 10^{3} \mathrm{~kg}$ of cow manure ha-1 $(\mathrm{P} 4)$, produces more fresh weight of stalks of $130.54 \mathrm{~g}$ compared to fresh weight of stalks in soil treatment, without fertilizer (P0), soil treatment, without fertilizer (P0), soil treatment, $138 \mathrm{~kg} \mathrm{~N} \mathrm{ha}^{-1}(\mathrm{P} 1)$, soil treatment, $136 \mathrm{~kg} \mathrm{~K} \mathrm{ha}^{-1}(\mathrm{P} 2)$, soil treatment, $\mathrm{N}$ and $\mathrm{K}, 138$ and $136 \mathrm{~kg} \mathrm{ha}^{-1}$ (P3), soil treatment, $20 \times 103 \mathrm{~kg}$ of cow manure ha, $136 \mathrm{~kg} \mathrm{~K} \mathrm{ha}^{-1}(\mathrm{P} 6)$ and soil treatment, $20 \times 10^{3} \mathrm{~kg}$ of cow manure $\mathrm{ha}^{-1}, \mathrm{~N}$ and $\mathrm{K}, 138$ and $136 \mathrm{~kg} \mathrm{ha}^{-1}(\mathrm{P} 7)$, but not significantly different from soil treatment, $20 \times 10^{3} \mathrm{~kg}$ of cow manure $\mathrm{ha}^{-1}, 138 \mathrm{~kg} \mathrm{~N}^{-1}(\mathrm{P} 5)$. Furthermore, the smallest fresh weight on the stalk is in the soil treatment, without fertilizer (P0) of $58.27 \mathrm{~g}$.

Fresh weight of harvest roots in soil treatment, $20 \times 10^{3} \mathrm{~kg}$ of cow manure ha-1 $(\mathrm{P} 4)$ more leaf weight of $79.75 \mathrm{~g}$ compared to soil treatment, without fertilizer (P0), soil treatment, without fertilizer (P0), soil treatment, $138 \mathrm{~kg} \mathrm{~N} \mathrm{ha}^{-1}(\mathrm{P} 1)$, soil treatment, $136 \mathrm{~kg} \mathrm{~K} \mathrm{ha}^{-1}(\mathrm{P} 2)$, soil treatment, $\mathrm{N}$ and $\mathrm{K}, 138$ and $136 \mathrm{~kg} \mathrm{ha}^{-1}(\mathrm{P} 3)$, and soil treatment, $20 \times 10^{3} \mathrm{~kg}$ of cow manure $\mathrm{ha}^{-1}, \mathrm{~N}$ and $\mathrm{K}, 138$ and $136 \mathrm{~kg} \mathrm{ha}^{-1}(\mathrm{P} 7)$, but not significantly different from soil treatment, $20 \times 10^{3} \mathrm{~kg}$ of cow manure ha-1, $138 \mathrm{~kg} \mathrm{~N} \mathrm{ha}^{-1}(\mathrm{P} 5)$ and Soil treatment, $20 \times 10^{3} \mathrm{~kg}$ of cow manure ha-1, $136 \mathrm{~kg} \mathrm{~K} \mathrm{ha}^{-1}(\mathrm{P} 6)$. Furthermore, the smallest fresh root weight was soil treatment, without fertilizer (P0) of $35.13 \mathrm{~g}$.

Total fresh weight of harvest on soil treatment, $20 \times 10^{3}$ $\mathrm{kg}$ of cow manure $\mathrm{ha}^{-1}(\mathrm{P} 4)$ more leaf weight of $79.75 \mathrm{~g}$ compared to soil treatment, without fertilizer (P0), soil treatment, without fertilizer $(\mathrm{P} 0)$, soil treatment, $138 \mathrm{~kg} \mathrm{~N}^{-}$ ${ }^{1}(\mathrm{P} 1)$, soil treatment, $136 \mathrm{~kg} \mathrm{~K} \mathrm{ha}^{-1}(\mathrm{P} 2)$, soil treatment, $\mathrm{N}$ and $\mathrm{K}, 138$ and $136 \mathrm{~kg} \mathrm{ha}^{-1}(\mathrm{P} 3)$, and soil treatment, $20 \times 10^{3} \mathrm{~kg}$ cow manure fertilizer ha ${ }^{-1}, \mathrm{~N}$ and $\mathrm{K}, 138$ and $136 \mathrm{~kg} \mathrm{ha}^{-1}(\mathrm{P} 7)$, but not significantly different from soil treatment, $20 \times 10^{3} \mathrm{~kg}$ cow manure ha-1 $138 \mathrm{~kg} \mathrm{~N} \mathrm{ha}^{-1}(\mathrm{P} 5)$ and treatment soil, 20x10 $\mathrm{kg}$ of cow manure ha-1, $136 \mathrm{~kg} \mathrm{~K} \mathrm{ha}^{-1}(\mathrm{P} 6)$. Furthermore, the smallest total fresh weight is soil treatment, without fertilizer (P0) of $111.57 \mathrm{~g}$.

\section{Harvest Dry Weight}

The results of the analysis of variance showed that the addition of organic and inorganic fertilizers had a significant effect on dry weight $(\mathrm{p}<0.05)$. The average dry weight of the harvest is presented in Table 12.

Based on the presentation of Table 12, the dry weight of harvested leaves on soil treatment, $20 \times 10^{3} \mathrm{~kg}$ of cow manure fertilizer $\mathrm{ha}^{-1}(\mathrm{P} 4)$, is $11.36 \mathrm{~g}$ more leaf weight compared to soil treatment, without fertilizer (P0), soil treatment, without fertilizer (P0), soil treatment, $138 \mathrm{~kg} \mathrm{~N} \mathrm{ha}^{-1}(\mathrm{P} 1)$, soil treatment, $136 \mathrm{~kg} \mathrm{~K} \mathrm{ha}^{-1}(\mathrm{P} 2)$, soil treatment, $\mathrm{N}$ and $\mathrm{K}, 138$ and $136 \mathrm{~kg} \mathrm{ha}^{-1}(\mathrm{P} 3)$, and soil treatment, $20 \times 10^{3} \mathrm{~kg}$ of cow manure $\mathrm{ha}^{-1}, \mathrm{~N}$ and $\mathrm{K}, 138$ and $136 \mathrm{~kg} \mathrm{ha}^{-1}$ (P7), but not significantly different from soil treatment, $20 \times 10^{3} \mathrm{~kg}$ of cow manure $\mathrm{ha}^{-1}$, $138 \mathrm{~kg} \mathrm{~N} \mathrm{ha}^{-1}(\mathrm{P} 5)$ and soil treatment, $20 \times 10^{3} \mathrm{~kg}$ of cow manure ha-1, $136 \mathrm{~kg} \mathrm{~K} \mathrm{ha}^{-1}(\mathrm{P} 6)$. Furthermore, the smallest dry weight on leaves is soil treatment, without fertilizer (P0) of $5.40 \mathrm{~g}$.

Furthermore, the harvest dry weight of the stalk in soil treatment, $20 \times 10^{3} \mathrm{~kg}$ of cow manure ha ${ }^{-1}(\mathrm{P} 4)$, produces 24.88 $\mathrm{g}$ more fresh weight of the stalk than the dry weight of the stalk in soil treatment, without fertilizer (P0), soil treatment, without fertilizer ( $\mathrm{P} 0$ ), soil treatment, $138 \mathrm{~kg} \mathrm{~N} \mathrm{ha}^{-1}(\mathrm{P} 1)$, soil treatment, $136 \mathrm{~kg} \mathrm{~K} \mathrm{ha}^{-1}(\mathrm{P} 2)$, giving $\mathrm{N}$ fertilizer at a dose of $12.3 \mathrm{~g} / \mathrm{pot}+\mathrm{K}$ at a dose of $12.1 \mathrm{~g} /$ pot (P3 ), soil treatment, $20 \times 10^{3} \mathrm{~kg}$ of cow manure $\mathrm{ha}^{-1}, 136 \mathrm{~kg} \mathrm{~K} \mathrm{ha}^{-1}(\mathrm{P} 6)$ and soil treatment, $20 \times 10^{3} \mathrm{~kg}$ of cow manure $\mathrm{ha}^{-1}, \mathrm{~N}$ and $\mathrm{K}, 138$ and $136 \mathrm{~kg} \mathrm{ha}^{-1}(\mathrm{P} 7)$, but not significantly different from soil

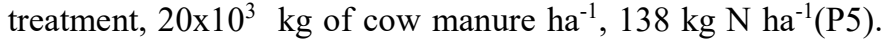
Furthermore, the smallest dry weight on the stalk is the provision of $\mathrm{N}$ fertilizer at a dose of $12.3 \mathrm{~g} / \mathrm{pot}+\mathrm{K}$ at a dose of $12.1 \mathrm{~g} /$ pot (P3), amounting to $11.99 \mathrm{~g}$.

Harvest dry weight of roots in soil treatment, $20 \times 10^{3} \mathrm{~kg}$ of cow manure ha ${ }^{-1}(\mathrm{P} 4)$ more weight of dry roots of $9.55 \mathrm{~g}$ compared to soil treatment, without fertilizer (P0), soil treatment, without fertilizer ( $\mathrm{P} 0)$, soil treatment, $138 \mathrm{~kg} \mathrm{~N}^{-}$ ${ }^{1}(\mathrm{P} 1)$, soil treatment, $136 \mathrm{~kg} \mathrm{~K} \mathrm{ha}^{-1}(\mathrm{P} 2)$, soil treatment, $20 \times 10^{3}$ $\mathrm{kg}$ cow manure ha-1, $136 \mathrm{~kg} \mathrm{~K} \mathrm{ha}^{-1}$ (P6) and soil treatment, $20 \times 10^{3} \mathrm{~kg}$ cow manure fertilizer ha ${ }^{-1}, \mathrm{~N}$ and $\mathrm{K}, 138$ and 136 $\mathrm{kg} \mathrm{ha}^{-1}(\mathrm{P} 7)$, but not significantly different from giving $\mathrm{N}$ fertilizer at a dose of $12.3 \mathrm{~g} / \mathrm{pot}+\mathrm{K}$ at a dose of $12.1 \mathrm{~g} / \mathrm{pot}$

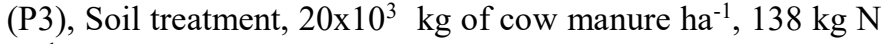
$\mathrm{ha}^{-1}(\mathrm{P} 5)$. Furthermore, the smallest root dry weight is soil treatment, without fertilizer (P0) of $3.09 \mathrm{~g}$.

The total dry weight of harvest on soil treatment, $20 \times 10^{3}$ $\mathrm{kg}$ of cow manure ha ${ }^{-1}(\mathrm{P} 4)$ more leaf weight of $45.78 \mathrm{~g}$ compared to soil treatment, without fertilizer (P0), soil treatment, without fertilizer (P0), soil treatment, $138 \mathrm{~kg} \mathrm{~N}^{-}$ ${ }^{1}(\mathrm{P} 1)$, soil treatment, $136 \mathrm{~kg} \mathrm{~K} \mathrm{ha}^{-1}(\mathrm{P} 2)$, giving $\mathrm{N}$ fertilizer at a 
dose of $12.3 \mathrm{~g} /$ pot $+\mathrm{K}$ at a dose of $12.1 \mathrm{~g} /$ pot (P3), soil treatment, $20 \times 10^{3} \mathrm{~kg}$ of fertilizer cow manure $\mathrm{ha}^{-1}, 136 \mathrm{~kg} \mathrm{~K}$ $\mathrm{ha}^{-1}(\mathrm{P} 6)$ and soil treatment, $20 \times 10^{3} \mathrm{~kg}$ of cow manure ha ${ }^{-1}, \mathrm{~N}$ and $\mathrm{K}, 138$ and $136 \mathrm{~kg} \mathrm{ha}^{-1}(\mathrm{P} 7)$, but not significantly different from soil treatment, $20 \times 10^{3} \mathrm{~kg}$ of cow manure $\mathrm{ha}^{-1}, 138 \mathrm{~kg} \mathrm{~N}$ $\mathrm{ha}^{-1}(\mathrm{P} 5)$. Furthermore, the smallest total dry weight is soil treatment, without fertilizer (P0) of $20.98 \mathrm{~g}$.

\section{Chlorophyll content}

The results of the analysis of variance showed that the addition of organic and inorganic fertilizers had a significant effect on chlorophyll content $(p<0.05)$. The average chlorophyll content is presented in Table 13.

Based on the presentation of Table 13, that soil treatment, $20 \times 10^{3} \mathrm{~kg}$ of cow manure ha ${ }^{-1}(\mathrm{P} 4)$ yields 0,8041 $\mathrm{mg} . \mathrm{g}^{-1}$ higher (chlorophyll A) than soil treatment, without fertilizer (P0) soil treatment, $138 \mathrm{~kg} \mathrm{~N} \mathrm{ha}^{-1}(\mathrm{P} 1)$, soil treatment, $136 \mathrm{~kg} \mathrm{~K} \mathrm{ha}^{-1}(\mathrm{P} 2)$, soil treatment, $\mathrm{N}$ and $\mathrm{K}, 138$ and $136 \mathrm{~kg} \mathrm{ha}^{-1}(\mathrm{P} 3)$, soil treatment, $20 \times 10^{3} \mathrm{~kg}$ cow manure ha-1, $138 \mathrm{~kg} \mathrm{~N}^{-1}(\mathrm{P} 5)$, soil treatment, $20 \times 10^{3} \mathrm{~kg}$ of cow manure $\mathrm{ha}^{-1}, 136 \mathrm{~kg} \mathrm{~K} \mathrm{ha}^{-1}(\mathrm{P} 6)$, soil treatment, $20 \times 10^{3} \mathrm{~kg}$ of cow manure ha ${ }^{-1}, \mathrm{~N}$ and $\mathrm{K}, 138$ and $136 \mathrm{~kg} \mathrm{ha}^{-1}(\mathrm{P} 7)$. Furthermore, the lowest amount of chlorophyll content was found in soil treatment, without fertilizer (P0) of 0, $697 \mathrm{mg} . \mathrm{g}^{-1}$

Chlorophyll b content, soil treatment, $20 \times 10^{3} \mathrm{~kg}$ of cow manure ha ${ }^{-1}(\mathrm{P} 4)$ produced higher chlorophyll $\mathrm{b}$ of $1.121 \mathrm{mg} . \mathrm{g}^{-}$ ${ }^{1}$ than soil treatment, without fertilizer (P0) soil treatment, 138 $\mathrm{kg} \mathrm{N}$ ha $^{-1}(\mathrm{P} 1)$, treatment soil, $136 \mathrm{~kg} \mathrm{~K} \mathrm{ha}^{-1}(\mathrm{P} 2)$, soil treatment, $\mathrm{N}$ and $\mathrm{K}, 138$ and $136 \mathrm{~kg} \mathrm{ha}^{-1}(\mathrm{P} 3)$, soil treatment, $20 \times 10^{3} \mathrm{~kg}$ cow manure $\mathrm{ha}^{-1}, 138 \mathrm{~kg} \mathrm{~N}^{-1}(\mathrm{P} 5)$, soil treatment, $20 \times 10^{3} \mathrm{~kg}$ of cow manure ha-1, $136 \mathrm{~kg} \mathrm{~K} \mathrm{ha}^{-1}(\mathrm{P} 6)$, soil treatment, $20 \times 10^{3} \mathrm{~kg}$ of cow manure $\mathrm{ha}^{-1}, \mathrm{~N}$ and $\mathrm{K}, 138$ and $136 \mathrm{~kg} \mathrm{ha}^{-1}(\mathrm{P} 7)$. Furthermore, the lowest amount of chlorophyll content was found in soil treatment, without fertilizer (P0) of $0,826 \mathrm{mg} \cdot \mathrm{g}^{-1}$.

The total chlorophyll content in soil treatment, $20 \times 10^{3} \mathrm{~kg}$ of cow manure ha- ${ }^{-1}(\mathrm{P} 4)$, produced a higher total chlorophyll of $1.523 \mathrm{mg} . \mathrm{g}^{-1}$ compared to soil treatment, without fertilizer (P0) soil treatment, $138 \mathrm{~kg} \mathrm{~N} \mathrm{ha}^{-1}(\mathrm{P} 1)$, treatment soil, $136 \mathrm{~kg} \mathrm{~K}^{-} \mathrm{a}^{-}$ ${ }^{1}(\mathrm{P} 2)$, soil treatment, $\mathrm{N}$ and $\mathrm{K}, 138$ and $136 \mathrm{~kg} \mathrm{ha}^{-1}(\mathrm{P} 3)$, soil treatment, 20x10 $\mathrm{kg}$ cow manure $\mathrm{ha}^{-1}, 138 \mathrm{~kg} \mathrm{~N}^{-1}(\mathrm{P} 5)$, soil treatment, $20 \times 10^{3} \mathrm{~kg}$ of cow manure ha-1, $136 \mathrm{~kg} \mathrm{~K}^{-} \mathrm{ha}^{-}$ ${ }^{1}(\mathrm{P} 6)$, soil treatment, $20 \times 10^{3} \mathrm{~kg}$ of cow manure $\mathrm{ha}^{-1}, \mathrm{~N}$ and $\mathrm{K}$, 138 and $136 \mathrm{~kg} \mathrm{ha}^{-1}(\mathrm{P} 7)$. Furthermore, the lowest amount of chlorophyll content was found in soil treatment, without fertilizer (P0) of $1.523 \mathrm{mg} \cdot \mathrm{g}^{-1}$

Clover plants need nutrients in order to grow. Good growth can produce higher biomass. So that the yields also increase. The application of various doses of organic and inorganic fertilizers gave different results and effects on stalk length, root length, stolon length, and number of tillers. fresh weight of leaves, roots, stalks and total dry weight of leaves, roots, stalks and total. Based on the observation that the efforts to provide various doses of organic and inorganic fertilizers can support the growth of clover plants. This can be seen from the results of its growth which also affect the biomass of the clover plant.

The results of the analysis show that the age of observation 4-12 DAP soil treatment, $20 \times 10^{3} \mathrm{~kg}$ of cow manure $\mathrm{ha}^{-1}, 136 \mathrm{~kg} \mathrm{~K} \mathrm{ha}^{-1}(\mathrm{P} 6)$ are able to produce longer stalks than other treatments. The combination of organic fertilizers from cow manure and inorganic $\mathrm{K}$ fertilizers can meet the needs of the clover plant so that the stem length is longer than the treatment without fertilization (control), single inorganic fertilization and organic fertilization from cow manure. Based on the results of research from [44], increasing the $\mathrm{K}$ content applied from 0 to $120 \mathrm{~kg} \mathrm{ha}^{-1}$ increased the average plant height by about $7 \%$ compared to the control treatment. Similar results reported that the application of $\mathrm{K}$ at $125 \mathrm{~kg} \mathrm{ha}^{-1}$ had shown significantly the highest plant height in shallots. In the research of [45], the maximum root length yield was $26.5 \mathrm{~cm}$ in green beans obtained from treatment given a higher dose of $\mathrm{K}$ fertilizer. The application of $\mathrm{K}$ fertilizer is able to increase root length and produce higher potassium levels.

The stolon is an extension of the clover plant's shoot that grows horizontally parallel to the soil surface. The stolons in this study appeared and grew at 12 DAP. The longest stolon length in clover was produced by soil treatment, $20 \times 10^{3} \mathrm{~kg}$ of cow manure $h^{-1}(\mathrm{P} 4)$ compared to other treatments. This proves that the application of organic cow manure fertilizer is more supportive of the growth of the semanggi plant so that its growth is more optimal. The provision of organic material in the form of cow manure can be an effort to improve soil quality.

But at $32 \mathrm{DAP}$, the longest stolon was produced in the soil treatment, $136 \mathrm{~kg} \mathrm{~K} \mathrm{ha}^{-1}(\mathrm{P} 2)$, soil treatment, $136 \mathrm{~kg} \mathrm{~K}$ ha $^{-}$ ${ }^{1}(\mathrm{P} 2)$ and soil treatment, $20 \times 10^{3} \mathrm{~kg}$ of cow manure $\mathrm{ha}^{-1}, 138$ $\mathrm{kg} \mathrm{N} \mathrm{ha}{ }^{-1}(\mathrm{P} 5)$. Based on the observations at $32 \mathrm{DAP}$, it can be seen that the organic fertilizer from cow manure and inorganic $\mathrm{N}$ fertilizers given can support the growth of the clover plant, especially in its stolon. Cow manure organic fertilizer and inorganic $\mathrm{N}$ fertilizer when combined can also affect the growth of longer stolons. The results of this study can be seen that organic fertilizers from cow manure and inorganic fertilizers containing $\mathrm{N}$ nutrients can be absorbed optimally by the semanggi plants. This is because $\mathrm{N}$ nutrients are fast release fertilizers.

This research was conducted in a green house, so there is no effect of rainfall on plant growth. Clover plants are given water regularly according to the watering schedule, so that they can control the $\mathrm{N}$ fertilizer given and can dissolve in water according to the dosage. The loss of fertilizer due to leaching was very small. in this study. In accordance with the statement of [46] that nitrate dissolves easily in the soil, especially in areas with high rainfall. However, because the research on soil treated with N-NH4 + and N-No3- was made in the dry season and irrigation was carried out by providing water as needed. So that it does not cause excess water and does not cause fertilizer $\mathrm{N}$ leaching. The longer root length in this study resulted in soil treatment, $20 \times 10^{3} \mathrm{~kg}$ of cow manure $\mathrm{ha}^{-1}(\mathrm{P} 4)$ compared to control treatment or other treatments. It can be judged that the organic fertilizer from cow manure is given a crumb texture, so that the particles that make up the fertilizer can easily decompose in the soil. In addition, this organic fertilizer from cow manure contains complete NPK nutrients even though the percentage of each nutrient element is small. According to [47] statement that cow manure has a high fiber content, namely cellulose. In the organic fertilizer, cow manure contains a high enough $\mathrm{C} / \mathrm{N}$ ratio, namely $>40$, 
the macro element content is $0.5 \% \mathrm{~N} ; 0.25 \% \mathrm{P}_{2} \mathrm{O}_{5} ; 0.5 \% \mathrm{~K}_{2} \mathrm{O}$ and $0.5 \%$ moisture content.

The ability of organic fertilizer from cow manure that can be integrated with the planting medium in a polybag, makes it easier for the roots to grow well. So, the length is better than other treatments. According to [48]-[52] stated that organic cow fertilizer can improve the chemical, biological, and physical properties of the soil. These physical properties can improve soil structure, can improve soil chemical properties into a function of soil chemical properties and biological properties can make the soil looser because in cow's organic fertilizer there are microorganisms that can break down organic matter so that the soil is more loose. According to research by [53] root vigor in organic fertilizer application was lower than inorganic fertilizer application in 20 DAP. But the root strength of the two treatments was almost the same at 40 DAP. From 60 DAP of Stevia rebaudiana Bertoni, the root vigor of organic fertilizer was $0.481 \mathrm{mg} / \mathrm{g}$, and the root vigor of inorganic fertilizer was $0.425 \mathrm{mg} / \mathrm{g}$, so that the root vigor of organic fertilizer was very high. Along with the growth process, the root strength of the two treatments began to decrease, but there was a decrease in the root growth rate of organic fertilizers which was slower than the cultivation of chemical fertilizers, and until the yield of the root strength from cultivation of organic fertilizers was higher than that of inorganic fertilizers.

Leaves become plant organs used for photosynthesis. From the research results, soil treatment, $20 \times 10^{3} \mathrm{~kg}$ of cow manure fertilizer ha $\mathrm{a}^{-1}(\mathrm{P} 4)$ produced more and wider leaves than the control treatment, $\mathrm{N}$ fertilizer treatment, $\mathrm{K}$ fertilizer treatment or a combination of both. Soil treatment, $20 \times 10^{3} \mathrm{~kg}$ of cow manure ha ${ }^{-1}(\mathrm{P} 4)$ gives variations in the number and area of leaves. It is suspected that organic fertilizer from cow manure is sufficient to provide nutrients in the soil and can support the growth of the clover plant. Sufficient nutrients will make the clover plant able to carry out the photosynthesis process properly. So that the number of leaves is more and the leaf area is wider. The results of this study are the same as those of [54] that the increase in leaf area also indicates that it may be due to nitrogen supply from manure, Sesamum indicum L [55], in wheat [56].

Nitrogen gives leaves their green color and is beneficial in enhancing all plant development at all stages. Sufficient nitrogen supply is also beneficial in the photosynthesis process. Produced a significant effect on 21 DAP of $4 \mathrm{~kg} / \mathrm{plot}$ of cow manure on the number of leaves of mustard plants. In the process of leaf vegetative growth, plants need more nitrogen. In addition, it also affects the leaf area parameter which produces wider leaves in the treatment of $4 \mathrm{~kg}$ of cow manure / plot compared to the treatment of urea fertilizer [57]. This is because the mustard plant absorbs more nutrients in cow manure compared to the addition of volatile urea. So that what goes into the soil and is absorbed by plants is small in number. Research from [58] also supports that the application of a single inorganic fertilizer such as $\mathrm{N}$ or $\mathrm{P}$ alone has no effect on the increase in total leaf area recorded at high $\mathrm{N}$ or $\mathrm{P}$ conditions compared to low $\mathrm{N}$ or $\mathrm{P}$ conditions, which shows that the relatively high nutrient supply had little effect on leaf expansion of 'Hongyang' kiwifruit. This is because other environmental factors such as water or light may be the main limiting factors directly affecting further leaf expansion when there is an adequate supply of nutrients. There is little effect on the total leaf count when a single inorganic fertilizer containing just one nutrient is applied together with an organic fertilizer.

Stomata in soil treatment, $20 \times 10^{3} \mathrm{~kg}$ of cow manure ha ${ }^{-1}$ (P4) produced more stomata, wider and longer in shape than in the control treatment without N, K, Cow Manure (P0). The treatment that resulted in wider leaves also resulted in a greater number of stomata, wider and longer. According to the statement of [59] that the size of the stomata is getting smaller if the density of the stomata is getting denser because the number of stomata is also influenced by the size of the stomata, namely the length and width. This is related to the photosynthesis process. the photosynthesis process. In the research of 49, it was found that the stomata density of oil palm plants had not been the most dense, namely in the treatment given inorganic fertilizers. Even so, the leaf chlorophyll content tended to decrease at the 8th month compared to the 4th month after planting. The application of organic fertilizers and compound NPK up to the highest dose has not been able to increase the chlorophyll content of immature palm oil by the end of the year. This is predicted because the fertilization dose is still insufficient or plants need a longer time to respond to fertilization.

Fresh weight in plants is the weight that shows the result of metabolic activity in clover plants. Metabolic activity is the process by which chemical reactions occur so that plants can survive. In this study, the leaves, roots, and total fresh weight were observed. The fresh weight of the roots showed that the results varied for each observation age, but the soil treatment, $20 \times 10^{3} \mathrm{~kg}$ of cow manure $\mathrm{ha}^{-1}(\mathrm{P} 4)$ was able to produce the heaviest root fresh weight compared to other varieties. Except at the age of 12,16, and 20 DAP observations, the treatment of cow manure at a dose of $800 \mathrm{~g} / \mathrm{pot}+\mathrm{K}$. fertilizer at a dose of $12.1 \mathrm{~g} /$ pot (P6) also produced heavier root fresh weight. The assistance of adding potassium fertilizer to the provision of organic cow manure in treatment P6 can help plants form carbohydrates from photosynthesis. In the journal [59] explains that $\mathrm{K}$ fertilization is an important fertilizer in increasing plant growth and yield. There are various sources of potassium fertilizer and based on the potassium content and type of chemical formula, this fertilizer can be used in different soil conditions. Generally, $\mathrm{K}$ is usually taken up earlier than nitrogen and phosphorus and its absorption increases faster than dry matter production. This means that $\mathrm{K}$ accumulates early in the growing period and is then transferred to other parts of the plant. In terms of the growth parameters of leaf fresh weight and total, it can be seen that organic fertilizer from cow manure is more capable of producing a treatment weight of soil treatment, $20 \times 10^{3} \mathrm{~kg}$ of cow manure ha ${ }^{-1}(\mathrm{P} 4)$ which is heavier than other treatments. This is because the nutrients contained in the organic fertilizer of cow manure can be used optimally in the photosynthesis process. So that it can affect the fresh weight of each age of observation.

Dry weight is the accumulation of $\mathrm{CO} 2$ assimilation during plant growth and development. Based on the results of the study, the dry weight of the roots, leaves and total was the heaviest, namely the soil treatment, $20 \times 10^{3} \mathrm{~kg}$ of cow manure 
$\mathrm{ha}^{-1}(\mathrm{P} 4)$. This can be due to the fact that fertilizer is based on the statement of [60] that organic fertilizer from cow manure is one of the best organic fertilizers available and is a very valuable resource. This type of fertilizer can increase soil fertility and increase the development of the root system and plant vigor and make it less susceptible to disease and pest attacks. In addition, cow manure organic fertilizer is an excellent growing medium for garden plants. The organic fertilizer is mixed into the soil or used as a growing medium for plants and vegetables as a nutrient-rich fertilizer. Cow manure organic fertilizer is usually used before planting, that is, at the beginning because the mineralization process is slow.

\section{Biomass of Growth and Yield Components of Clover Plants at Various Doses of Organic and Inorganic Fertilizers}

High fresh yields of yield in soil-treated plants, soil treatment, $20 \times 10^{3} \mathrm{~kg}$ of cow manure $\mathrm{ha}^{-1}(\mathrm{P} 4)$ compared to the control treatment. However soil, $20 \times 10^{3} \mathrm{~kg}$ of cow manure ha ${ }^{-1}, 138 \mathrm{~kg}$

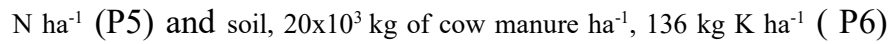
produces leaf and root fresh weights that do not differ from fresh weights resulting from soil treatment, $20 \times 10^{3} \mathrm{~kg}$ of cow manure ha ${ }^{-1}(\mathrm{P} 4)$. Meanwhile, stalk fresh weight and total in soil treatment was $20 \times 10^{3} \mathrm{~kg}$ of cow manure ha- ${ }^{-1}, 138 \mathrm{~kg} \mathrm{~N}^{-}$ ${ }^{1}$ (P5) produced fresh weight that did not differ from soil treatment, $20 \times 10^{3} \mathrm{~kg}$ of cow manure ha ${ }^{-1}(\mathrm{P} 4)$. Based on the results of this study, it can be said that the application of organic fertilizer from cow manure is able to provide sufficient nutrients for the clover plant so that it can survive to produce higher biomass, it is in accordance with the opinion[61]. In the journal [60] that the presence of sufficient K-available in the soil ensures plant survival. When sufficient potassium is available in plants, plants are more resistant to pathogens and stimulate root growth [62]-[64]. Better root growth [65] will result in more nutrient absorption so that it can be used in metabolic processes, especially protein synthesis from amino acids and ammonium ions. The results of this synthesis can affect plant growth and production [66]. The special effects of potassium in nutrient absorption [67], respiratory regulation, transpiration, enzymes and affect photosynthetic translocation [68], [69] which regulates the transportation system, as a result photosynthetic can be well distributed so that it does not occur at the site of photosynthetic accumulation. Research from [44] also resulted that applying $\mathrm{K}$ at $120 \mathrm{~kg} \mathrm{ha}^{-1}$ increased tuber yields by about $47 \%$ compared to control treatment (12.96 tonnes $\mathrm{ha}^{-1}$ ). Likewise, the results of research by [70] showed that the yield of sweet corn crops, [71] rice, [72] Portulaca oleracea L, increased due to a combination of organic fertilizer with NPK fertilizer compared to control treatment. The recommended dosage from the research is three-quarter NPK and half of organic fertilizer.

The yield of dry weight in plants was also higher in soil treatment, $20 \times 10^{3} \mathrm{~kg}$ of cow manure ha ${ }^{-1}(\mathrm{P} 4)$ compared to the control treatment. This can be caused by plants that are more optimal in absorbing organic fertilizers from cow manure. Compared with the application of a single inorganic $\mathrm{N}$ fertilizer which is volatile than that which is absorbed by the plant. Whereas in soil treatment, $20 \times 10^{3} \mathrm{~kg}$ of cow manures $\mathrm{ha}^{-1}, 138 \mathrm{~kg} \mathrm{~N} \mathrm{ha}^{-1}(\mathrm{P} 5)$ yield of dry weight is also not different from soil treatment, $20 \times 10^{3} \mathrm{~kg}$ of cow manure ha ${ }^{-1}(\mathrm{P} 4)$. It is suspected that the addition of $\mathrm{N}$ fertilizer to the application of organic cow manure in soil treatment, $20 \times 10^{3} \mathrm{~kg}$ of cow manure ha ${ }^{-1}, 138 \mathrm{~kg} \mathrm{~N} \mathrm{ha}^{-1}$ (P5) can help the soil to avoid nitrogen deficiency. With the addition of $\mathrm{N}$ from a single inorganic fertilizer, it can affect the absorption of nitrogen more effectively. So that it can meet the vegetative needs of the clover plant and can increase the plant biomass. This is similar to the results of research from [44] that the K application produces a very significant effect. The increased $\mathrm{K}$ content encouraged tubers with a much higher dry matter content compared to unfertilized plots. The maximum dry matter content of shallot tubers $(10.42 \%)$ was recorded with $\mathrm{K}$ application at a higher level of $120 \mathrm{~kg} \mathrm{ha}^{-1}$. On the other hand, a minimum dry matter content $(9.20 \%)$ was detected in the control for $\mathrm{K}$.

In general, agricultural crop production depends on many factors that can increase soil fertility, one of which is through the application of organic and inorganic fertilizers. The need to use renewable energy and in order to reduce the cost of fertilizing crops, therefore the use of organic fertilizers is starting to be developed all over the world [73], vegetative growth of tomato (Lycopersicum esculentum Mill.) [74], yield and biomass Vetiveria zizanioides L. [75]

\section{CONCLUSION}

The results prove that the soil combination, $20 \times 10^{3} \mathrm{~kg}$ of cow manure $\mathrm{ha}^{-1}(\mathrm{P} 4)$ was effective in increasing the growth and yield of semanggi plant biomass, which was significantly different compared to other treatments at the age of 32 DAP. This is shown in the growth and yield parameters of plant biomass such as stolon length $(74.78 \mathrm{~cm})$, number of leaves (160.44), leaf area $\left(1379.28 \mathrm{~cm}^{2}\right)$, root length $(23.85 \mathrm{~cm})$, stomata density and number of stomata $(13,25)$; Stomata width $(10.87 \mathrm{~cm})$; Stomata length $(19.76 \mathrm{~cm})$, leaf fresh weight $(12,907 \mathrm{~g})$, leaf dry weight $(1,802 \mathrm{~g})$, total fresh weight $210,830 \mathrm{~g}$, total dry weight $7,823 \mathrm{~g}$, fresh leaf harvest weight $(64.19 \mathrm{~g})$; stem (130.54 g); root (79.75 g); total $274.48 \mathrm{~g})$, dry weight of leaf harvest (11.36 g); stem (24.88 g); root (9.55 g); total $45.78 \mathrm{~g}$ ) and chlorophyll a content $\left(0.804 \mathrm{mg} . \mathrm{g}^{-1}\right)$; chlorophyll b (1.121 mg.g $\left.\mathrm{g}^{-1}\right)$; and total chlorophyll $(1,924$ $\left.\mathrm{mg} \cdot \mathrm{g}^{-1}\right)$. Therefore, it is recommended to apply cow manure (organic fertilizer) which is good for Marsilea crenata Presl. and open up opportunities for further broader research.

\section{ACKNOWLEDGMENT}

Thank you to the author to the Directorate of Research and Community Service Directorate General of Research and Development Strengthening, Ministry of Research, Technology and Higher Education, Indonesia which has provided a dissertation research grant doctorate. Furthermore, thanks to the chairman and staff of research and community service institutions Trunojoyo Madura University, who have facilitated doctoral dissertation research activities, and the promoters and co-promoters who have guided this research in starting from proposals to research reports. 


\section{REFERENCES}

[1] A. Corli et al., "Coexistence of rice production and threatened plant species: testing Marsilea quadrifolia L. in N-Italy," Paddy Water Environ., 2021, doi: 10.1007/s10333-021-00840-z.

[2] I. Krolikiewicz-Renimel et al., "Protective effect of a Butea monosperma (Lam.) Taub. flowers extract against skin inflammation: Antioxidant, antiinflammatory and matrix metalloproteinases inhibitory activities," J. Ethnopharmacol., vol. 148, no. 2, pp. 537-543, 2013, doi: 10.1016/j.jep.2013.05.001.

[3] E. Launert, Marsileaceae. Balkema, 2003.

[4] S. Kumar Agarwal, S. Roy, P. Pramanick, P. Mitra, R. Gobato, and A. Mitra, "Marsilea quadrifolia: A floral species with unique medicinal properties," Parana $J$. Sci. Educ., vol. 4, no. 5, pp. 15-20, 2018.

[5] F. Rachmadiarti and G. Trimulyono, "Phytoremediation Capability of Water Clover (Marsilea Crenata (L). Presl.) in Synthetic $\mathrm{Pb}$ Solution," Appl. Ecol. Environ. Res., vol. 17, no. 4, pp. 9609-9619, 2019, doi: 10.15666/aeer/1704 96099619.

[6] H. M. Mustafa and G. Hayder, "Recent studies on applications of aquatic weed plants in phytoremediation of wastewater: A review article," Ain Shams Eng. J., vol. 12, no. 1, pp. 355-365, 2020, doi: 10.1016/j.asej.2020.05.009.

[7] M. Agil, H. Laswati, N. Purwitasari, and B. Ma'arif, "Analysis of heavy metal contents of marsilea crenata presl. leaves and soils from East Java Province, Indonesia," Pharmacogn. J., vol. 13, no. 1, pp. 17-22, 2021, doi: 10.5530/pj.2021.13.3.

[8] S. M. Belcher and A. Zsarnovszky, "Estrogenic actions in the brain: estrogen, phytoestrogens, and rapid intracellular signaling mechanisms," $J$. Pharmacol. Exp. Ther., vol. 299, no. 2, pp. 408-414, 2001.

[9] J. V Turner, S. Agatonovic- Kustrin, and B. D. Glass, "Molecular aspects of phytoestrogen selective binding at estrogen receptors," J. Pharm. Sci., vol. 96, no. 8, pp. 1879-1885, 2007.

[10] A. K. Tanwar, N. Dhiman, A. Kumar, and V. Jaitak, "Engagement of Phytoestrogens in Breast Cancer suppression: Structural classification and mechanistic approach," Eur. J. Med. Chem., p. 113037, 2020.

[11] T. Liu et al., "Recent advances in the anti- aging effects of phytoestrogens on collagen, water content, and oxidative stress," Phyther. Res., vol. 34, no. 3, pp. 435-447, 2020.

[12] K. Reinli and G. Block, "Phytoestrogen content of foods - a compendium of literature values," Nutr. Cancer, vol. 26, no. 2, pp. 123-148, 1996.

[13] A. Devkota and P. K. Jha, "Effect of integrated manuring on growth and yield of Centella asiatica(L.) Urb," Trop. Ecol., vol. 54, no. 1, pp. 89-95, 2013.

[14] M. Ghulamahdi, S. A. Aziz, N. Bermawie, and O. Trisilawati, "Studi penyiapan standar operasional prosedur budidaya untuk produksi bioaktif mendukung standarisasi mutu pegagan," Lap. Has. Penelit. KKP3T, vol. 71, 2008.

[15] T. Trop, "Pengaruh Kombinasi NPK dan Pupuk Kandang terhadap Sifat Tanah dan Pertumbuhan serta Produksi Tanaman Caisim," vol. 14, no. 3, pp. 211219, 2009.

[16] R. Agromedia, Petunjuk pemupukan. AgroMedia, 2007.

[17] P. Lingga, Petunjuk penggunaan pupuk. Niaga Swadaya, 2001.

[18] S. Yang, F. Li, S. S. Malhi, P. Wang, D. Suo, and J. Wang, "Long- term fertilization effects on crop yield and nitrate nitrogen accumulation in soil in northwestern China," Agron. J., vol. 96, no. 4, pp. 1039-1049, 2004.

[19] L. R. Widowati, "Peranan pupuk organik terhadap efisiensi pemupukan dan tingkat kebutuhannya untuk tanaman sayuran pada tanah Inseptisols Ciherang, Bogor," J. Tanah Trop., vol. 14, no. 3, pp. 221-228, 2009.

[20] M. Arifin et al., "Pedogenesis Dan Klasifikasi Tanah Yang Berkembang Dari Dua Formasi Geologi Dan Umur Bahan Erupsi Gunung Tangkuban Perahu," soilrens, vol. 15, no. 1, 2017.

[21] I. Prater et al., "From fibrous plant residues to mineral-associated organic carbon-the fate of organic matter in Arctic permafrost soils," Biogeosciences, vol. 17, no. 13, pp. 3367-3383, 2020.

[22] D. Savy, F. Mercl, V. Cozzolino, R. Spaccini, S. Cangemi, and A. Piccolo, "Soil amendments with lignocellulosic residues of biorefinery processes affect soil organic matter accumulation and microbial growth," ACS Sustain. Chem. Eng., vol. 8, no. 8, pp. 3381-3391, 2020.

[23] F. Akbari, S. Fallah, M. Dahmardeh, and M. Pessarakli, "Interaction effects of nitrogen and phosphorus fertilizer on nitrogen mineralization of wheat residues in a calcareous soil," J. Plant Nutr., vol. 43, no. 1, pp. 1-12, 2020.

[24] J. L. Munera-Echeverri, V. Martinsen, L. T. Strand, G. Cornelissen, and J. Mulder, "Effect of conservation farming and biochar addition on soil organic carbon quality, nitrogen mineralization, and crop productivity in a light textured Acrisol in the sub-humid tropics," PLoS One, vol. 15, no. 2, p. e0228717, 2020.

[25] M. Badaruddin and D. W. Meyer, "Grain legume effects on soil nitrogen, grain yield, and nitrogen nutrition of wheat," Crop Sci., vol. 34, no. 5, pp. 1304-1309, 1994.

[26] J.-H. Chen, "The combined use of chemical and organic fertilizers and/or biofertilizer for crop growth and soil fertility," in International workshop on sustained management of the soil-rhizosphere system for efficient crop production and fertilizer use, 2006, vol. 16 , no. 20 , pp. $1-11$.

[27] H. A. Mupambwa and P. N. S. Mnkeni, "Optimizing the vermicomposting of organic wastes amended with inorganic materials for production of nutrient-rich organic fertilizers: a review," Environ. Sci. Pollut. 
Res., vol. 25, no. 11, pp. 10577-10595, 2018.

[28] S. Ye, T. Liu, and Y. Niu, "Effects of organic fertilizer on water use, photosynthetic characteristics, and fruit quality of pear jujube in northern Shaanxi," Open Chem., vol. 18, no. 1, pp. 537-545, 2020.

[29] Y.-C. Bai et al., "Soil chemical and microbiological properties are changed by long-term chemical fertilizers that limit ecosystem functioning," Microorganisms, vol. 8, no. 5, p. 694, 2020.

[30] R. Prasad and Y. S. Shivay, "Agronomic biofortification of plant foods with minerals, vitamins and metabolites with chemical fertilizers and liming," J. Plant Nutr., vol. 43, no. 10, pp. 1534-1554, 2020.

[31] M. Anwar, D. D. Patra, S. Chand, K. Alpesh, A. A. Naqvi, and S. P. S. Khanuja, "Effect of organic manures and inorganic fertilizer on growth, herb and oil yield, nutrient accumulation, and oil quality of French basil," Commun. Soil Sci. Plant Anal., vol. 36, no. 13-14, pp. 1737-1746, 2005.

[32] S. Sharafzadeh and K. Ordookhani, "Organic and bio fertilizers as a good substitute for inorganic fertilizers in medicinal plants farming," Aust. J. Basic Appl. Sci., vol. 5, no. 12, pp. 1330-1333, 2011.

[33] W. Bayu, N. F. G. Rethman, P. S. Hammes, and G. Alemu, "Effects of farmyard manure and inorganic fertilizers on sorghum growth, yield, and nitrogen use in a semi-arid area of Ethiopia," J. Plant Nutr., vol. 29, no. 2, pp. 391-407, 2006.

[34] N. Y. M. Naguib, "Organic vs chemical fertilization of medicinal plants: a concise review of researches," Adv. Environ. Biol., vol. 5, no. 2, pp. 394-400, 2011.

[35] W. Dikr and K. Belete, "Review on the effect of organic fertilizers, bio-fertilizers and inorganic fertilizers (NPK) on growth and flower yield of marigold (Targets erecta L.)," J. Agri. Sci. Res, vol. 5, pp. 192-204, 2017.

[36] A. S. Godara, U. S. Gupta, G. Lal, and R. Singh, "Influence of organic and inorganic source of fertilizers on growth, yield and economics of coriander (Coriandrum sativum L.)," Int J Seed Spice, vol. 4, no. 2, pp. 77-80, 2014.

[37] A. S. Godara, U. S. Gupta, G. Lal, and R. Singh, "Influence of organic and inorganic sources of fertilizers on growth, yield and economics of fennel (Foeniculum vulgare Mill.) cultivation under semi arid conditions," J. Spices Aromat. Crop., vol. 23, no. 2, pp. 200-204, 2014.

[38] N. K. Imnatemsu, S. Rout, and R. Debbarma, "Effect of Organic and Inorganic Fertilizers on Growth and Yield of Bottle Gourd (Lagenaria siceraria) Under Teak Based Agroforestry System," Ind. J. Pure App. Biosci, vol. 8, no. 3, pp. 388-395, 2020.

[39] S. Kazemalilou, B. A. Lajayer, and M. Ghorbanpour, "Increasing the Tolerance of Water-Deficit Stress in Plants with Integrated Application of Organic and Inorganic Fertilizers," Agri-Based Bioeconomy Reintegrating Trans-disciplinary Res. Sustain. Dev. Goals, p. 299, 2021.

[40] W. XIAO et al., "Effect of organic fertilizer application on the medicinal character, yield and disease resistance of Angelica sinensis," Acta Prataculturae Sin., vol. 30, no. 3, p. 189, 2021.

[41] S. Indrayani and A. Y. Perdani, "Metode koleksi dan pengamatan stomata tanaman garut menggunakan pewarna kuku," in Prosiding Seminar Nasional Masyarakat Biodiversity Indonesia, 2018, vol. 4, no. 2, pp. $158-162$.

[42] D. I. Arnon, "Copper enzymes in isolated chloroplasts. Polyphenoloxidase in Beta vulgaris," Plant Physiol., vol. 24, no. 1, p. 1, 1949.

[43] J. Kaufmann and A. G. Schering, "Analysis of variance ANOVA," Wiley StatsRef Stat. Ref. Online, 2014.

[44] M. Bekele, "Effects of different levels of potassium fertilization on yield, quality and storage life of onion (Allium cepa L.) at Jimma, Southwestern Ethiopia," $J$ Food Sci Nutr. 2018; 1 32-9. J Food Sci Nutr 2018 Vol. 1 Issue, vol. 2, 2018.

[45] C. KWIZERA, B. T. I. Ong'or, S. KABONEKA, F. NKESHIMANA, and N. AHIBONEYE, "Effects of Potassium Fertilizer on Bean growth and Yield parameters," 2019

[46] A. S. Nascente, M. da C. S. Carvalho, L. C. Melo, and P. H. Rosa, "Nitrogen management effects on soil mineral nitrogen, plant nutrition and yield of super early cycle common bean genotypes," Acta Sci. Agron., vol. 39, no. 3, pp. 369-378, 2017.

[47] P. Ayub S, "Meningkatkan Hasil Panen Dengan Pupuk Organik.” Agromedia Pustaka, 2010.

[48] A. Maltas, H. Kebli, H. R. Oberholzer, P. Weisskopf, and S. Sinaj, "The effects of organic and mineral fertilizers on carbon sequestration, soil properties, and crop yields from a long- term field experiment under a Swiss conventional farming system," L. Degrad. Dev., vol. 29, no. 4, pp. 926-938, 2018.

[49] S. Dadashi, M. Ghajar Sepanlou, and S. K. Mirnia, "Influence of organic compost compounds on soil chemical and physical properties," Int. J. Hum. Cap. Urban Manag., vol. 4, no. 1, pp. 15-22, 2019.

[50] S. Marinari, G. Masciandaro, B. Ceccanti, and S. Grego, "Influence of organic and mineral fertilisers on soil biological and physical properties," Bioresour. Technol., vol. 72, no. 1, pp. 9-17, 2000.

[51] A. O. Adekiya et al., "Different organic manure sources and NPK fertilizer on soil chemical properties, growth, yield and quality of okra," Sci. Rep., vol. 10, no. 1, pp. 1-9, 2020.

[52] T. T. Doan et al., "Site-specific effects of organic amendments on parameters of tropical agricultural soil and yield: A field experiment in three countries in Southeast Asia," Agronomy, vol. 11, no. 2, p. 348, 2021.

[53] X. Liu, G. Ren, and Y. Shi, "The effect of organic manure and chemical fertilizer on growth and development of Stevia rebaudiana Bertoni," Energy Procedia, vol. 5, pp. 1200-1204, 2011.

[54] Y. C. Hariadi, A. Y. Nurhayati, and P. Hariyani, "Biophysical monitoring on the effect on different composition of goat and cow manure on the growth response of maize to support sustainability," Agric. 
Agric. Sci. Procedia, vol. 9, pp. 118-127, 2016.

[55] N. R. Lokhande, N. K. Kalegore, H. V Bangar, and B. M. Wakchaure, "Growth and yield attributes of sesame (Sesamum indicum L.) as influenced by different organic manures," J. Pharmacogn. Phytochem., vol. 9, no. 6, pp. 750-752, 2020.

[56] A. Rehim et al., "Integrated use of farm manure and synthetic nitrogen fertilizer improves nitrogen use efficiency, yield and grain quality in wheat," Ital. J. Agron., vol. 15, no. 1, pp. 29-34, 2020.

[57] M. Kholidin, A. Rauf, and H. N. Barus, "Respon pertumbuhan dan hasil tanaman sawi (Brassica juncea L.) terhadap kombinasi pupuk organik, anorganik dan mulsa di Lembah Palu," J. Agrotekbis, vol. 4, no. 1, pp. 1-7, 2016.

[58] M. Zhang, D. Sun, Z. Niu, J. Yan, X. Zhou, and X. Kang, "Effects of combined organic/inorganic fertilizer application on growth, photosynthetic characteristics, yield and fruit quality of Actinidia chinesis cv "Hongyang," Glob. Ecol. Conserv., vol. 22, p. e00997, 2020.

[59] D. E. Rantau, E. A. Hafiizh, W. Rahman, and M. E. Tri, "Analisis Ukuran dan Kerapatan Stomata pada Artemisia annua Hasil Perlakuan Kolkisin," in Prosiding Seminar Nasional XXIII Kimia dalam Industri dan Lingkungan, 2014, pp. 45-52.

[60] H. Shaji, V. Chandran, and L. Mathew, "Organic fertilizers as a route to controlled release of nutrients," in Controlled Release Fertilizers for Sustainable Agriculture, Elsevier, 2021, pp. 231-245.

[61] S. V Vassilev, D. Baxter, L. K. Andersen, C. G. Vassileva, and T. J. Morgan, "An overview of the organic and inorganic phase composition of biomass," Fuel, vol. 94, pp. 1-33, 2012.

[62] S. V Belov et al., "An Activated Potassium Phosphate Fertilizer Solution for Stimulating the Growth of Agricultural Plants," Front. Phys. 8 618320. doi 10.3389/fphy, 2021.

[63] J. O. Omondi, N. Lazarovitch, S. Rachmilevitch, T. Kukew, U. Yermiyahu, and H. Yasuor, "Potassium and storage root development: focusing on photosynthesis, metabolites and soluble carbohydrates in cassava," Physiol. Plant., vol. 169, no. 2, pp. 169$178,2020$.

[64] P. Kumar, T. Kumar, S. Singh, N. Tuteja, R. Prasad, and J. Singh, "Potassium: A key modulator for cell homeostasis," J. Biotechnol., vol. 324, pp. 198-210, 2020.

[65] J. Zhang, X. Jiao, Q. Du, X. Song, J. Ding, and J. Li, "Effects of vapor pressure deficit and potassium supply on root morphology, potassium uptake, and biomass allocation of tomato seedlings," J. Plant Growth Regul., vol. 40, no. 2, pp. 509-518, 2021.

[66] E. E. Kandil, N. R. Abdelsalam, M. A. Mansour, H. M. Ali, and M. H. Siddiqui, "Potentials of organic manure and potassium forms on maize (Zea mays L.) growth and production," Sci. Rep., vol. 10, no. 1, pp. $1-11,2020$.

[67] H. Okada, T. Abedin, A. Yamamoto, T. Hayashi, and M. Hosokawa, "Production of low-potassium onions based on mineral absorption patterns during growth and development," Sci. Hortic. (Amsterdam),, vol. 267, p. 109252, 2020.

[68] Y. Wang, Z. Zhang, Y. Liang, Y. Han, Y. Han, and J. Tan, "High potassium application rate increased grain yield of shading-stressed winter wheat by improving photosynthesis and photosynthate translocation," Front. Plant Sci., vol. 11, p. 134, 2020.

[69] G. K. Pandey and S. Mahiwal, Role of Potassium in Plants. Springer, 2020.

[70] E. T. Sofyan and D. S. Sara, "The Effect of Organic and Inorganic Fertilizer Applications on N, P and K Uptake and Yield of Sweet Corn (Zea mays saccharata Sturt)," J. Trop. Soils, vol. 23, no. 3, pp. 111-116, 2019.

[71] A. Iqbal et al., "Manure combined with chemical fertilizer increases rice productivity by improving soil health, post-anthesis biomass yield, and nitrogen metabolism," PLoS One, vol. 15, no. 10, p. e0238934, 2020.

[72] H. Javadi, P. Rezvani Moghaddam, M. H. Rashed Mohasel, and M. J. Seghatoleslami, "Evaluation of Biomass Yield and Nitrogen and Phosphorus Efficiency Indicators of Portulaca (Portulaca oleracea L.) Affected by Organic, Chemical and Biological Fertilizers," Iran. J. F. Crop. Res., vol. 18, no. 3, pp. 309-322, 2020.

[73] O. T. Ayoola and O. N. Adeniyan, "Influence of poultry manure and NPK fertilizer on yield and yield components of crops under different cropping systems in south west Nigeria," African J. Biotechnol., vol. 5, no. $15,2006$.

[74] M. P. P. Minn, "IMPACT OF ORGANIC AND INORGANIC FERTILIZERS ON VEGETATIVE GROWTH OF TOMATO (Lycopersicum esculentum Mill.)."

[75] N. D. N. Priyadarshani, M. Amarasinghe, S. Subasinghe, I. R. Palihakkara, and H. Kumarasinghe, "Effect of organic and inorganic fertilizers on biomass production, oil yield and quality of vetiver (Vetiveria zizanioides L.)," 2013.

Creative Commons Attribution License 4.0 (Attribution 4.0 International ,CM3 BY 4.0) This article is published under the terms of the Creative Commons Attribution License 4.0 https://creativecommons.org/licenses/by/4.0/deed.e $\underline{\mathrm{n} U S}$ 
Table 1.Fertilizer treatment on Semanggi (Marsilea crenata) planted on aluvial soil

\begin{tabular}{|c|c|c|c|c|}
\hline \multirow{2}{*}{ Treatment (unit) } & Soil & Cow Manure (CM) & Nitrogen $(\mathbf{N})$ & Potassium (K) \\
\hline & \multicolumn{4}{|l|}{$\left(\mathrm{kg} \mathrm{ha}^{-1}\right)$} \\
\hline P0 & Soil & omitted & omitted & omitted \\
\hline $\mathrm{P} 1$ & Soil & omitted & 138 & Omitted \\
\hline $\mathrm{P} 2$ & Soil & omitted & omitted & 136 \\
\hline P3 & Soil & omitted & 138 & 136 \\
\hline $\mathrm{P} 4$ & Soil & $20.10^{3}$ & omitted & Omitted \\
\hline P5 & Soil & $20.10^{3}$ & 138 & Omitted \\
\hline P6 & Soil & $20.10^{3}$ & omitted & 136 \\
\hline P7 & Soil & $20.10^{3}$ & 138 & 136 \\
\hline
\end{tabular}

Table 2. Average stolon length for each observation age

\begin{tabular}{|c|c|c|c|c|c|c|}
\hline \multirow{3}{*}{$\begin{array}{l}\text { Treatment } \\
\text { (unit) }\end{array}$} & \multicolumn{6}{|c|}{ Stolon Length at The Age of Observation The Day After Planting (DAP) } \\
\hline & 12 & 16 & 20 & 24 & 28 & 32 \\
\hline & \multicolumn{6}{|l|}{$(\mathrm{cm})$} \\
\hline P0 & $3.97 \mathrm{a}$ & $7.62 \mathrm{a}$ & $14.38 \mathrm{a}$ & $19.25 \mathrm{a}$ & $24.39 \mathrm{a}$ & $34.13 \mathrm{a}$ \\
\hline P1 & $4.72 \mathrm{a}$ & $9.06 \mathrm{a}$ & $15.39 \mathrm{ab}$ & $22.29 \mathrm{a}$ & $28.33 \mathrm{a}$ & $42.56 \mathrm{a}$ \\
\hline P2 & $3.96 \mathrm{a}$ & $10.91 \mathrm{ab}$ & $20.29 \mathrm{abcd}$ & $25.96 \mathrm{ab}$ & $37.89 \mathrm{a}$ & $63.39 \mathrm{c}$ \\
\hline P3 & $4.61 \mathrm{a}$ & $11.87 \mathrm{abc}$ & $27.30 \mathrm{~cd}$ & $27.33 \mathrm{ab}$ & $30.19 \mathrm{a}$ & $41.18 \mathrm{a}$ \\
\hline P4 & $8.80 \mathrm{c}$ & $16.67 \mathrm{c}$ & $29.37 \mathrm{~d}$ & $41.08 \mathrm{c}$ & $56.16 \mathrm{~b}$ & $74.78 \mathrm{c}$ \\
\hline P5 & $5.84 \mathrm{ab}$ & $16.14 \mathrm{bc}$ & $25.34 \mathrm{bcd}$ & $26.68 \mathrm{ab}$ & $29.52 \mathrm{a}$ & $63.58 \mathrm{c}$ \\
\hline P6 & $7.74 \mathrm{bc}$ & $11.05 \mathrm{ab}$ & $27.19 \mathrm{~cd}$ & $34.69 \mathrm{bc}$ & $31.09 \mathrm{a}$ & $62.54 \mathrm{bc}$ \\
\hline P7 & $5.82 \mathrm{ab}$ & $9.95 \mathrm{a}$ & $17.92 \mathrm{abc}$ & $24.02 \mathrm{ab}$ & $29.99 \mathrm{a}$ & $48.44 \mathrm{ab}$ \\
\hline $\operatorname{LSD}(5 \%)$ & 2.80 & 5.29 & 10.60 & 12.14 & 16.01 & 14.91 \\
\hline C.V. (\%) & 28.12 & 25.90 & 27.33 & 25.05 & 27.33 & 15.82 \\
\hline
\end{tabular}

Note: Numbers accompanied by the same letter in the same row and column show no significant difference based on the LSD test at the 5\% level, CV = Coefficient of Variation, Day After Planting (DAP) 
Table 3. Average number of leaves for each observation age

\begin{tabular}{lllllllll}
\hline \multirow{2}{*}{$\begin{array}{l}\text { Treatment } \\
\text { (unit) }\end{array}$} & \multicolumn{7}{l}{ Number of Leaves at The Age of Observation The Day After Planting (DAP) } \\
\cline { 2 - 8 } & Strands & 8 & 12 & 16 & 20 & 24 & 28 & 32 \\
\hline P0 & $1.22 \mathrm{a}$ & $2.78 \mathrm{a}$ & $5.22 \mathrm{a}$ & $14.56 \mathrm{a}$ & $27.44 \mathrm{ab}$ & $70.56 \mathrm{~cd}$ & $54.00 \mathrm{ab}$ & $83.00 \mathrm{a}$ \\
P1 & $1.33 \mathrm{a}$ & $5.22 \mathrm{bc}$ & $5.78 \mathrm{ab}$ & $16.00 \mathrm{a}$ & $49.67 \mathrm{bc}$ & $69.89 \mathrm{~cd}$ & $64.78 \mathrm{ab}$ & $90.56 \mathrm{a}$ \\
P2 & $2.22 \mathrm{abc}$ & $3.67 \mathrm{ab}$ & $6.89 \mathrm{abc}$ & $14.22 \mathrm{a}$ & $26.44 \mathrm{a}$ & $47.11 \mathrm{ab}$ & $47.44 \mathrm{a}$ & $92.67 \mathrm{a}$ \\
P3 & $2.11 \mathrm{ab}$ & $3.11 \mathrm{a}$ & $6.22 \mathrm{abc}$ & $22.67 \mathrm{ab}$ & $38.56 \mathrm{ab}$ & $62.44 \mathrm{abc}$ & $68.22 \mathrm{ab}$ & $95.44 \mathrm{a}$ \\
P4 & $3.44 \mathrm{c}$ & $5.78 \mathrm{c}$ & $11.78 \mathrm{~d}$ & $29.22 \mathrm{~b}$ & $64.89 \mathrm{c}$ & $86.56 \mathrm{~d}$ & $142.44 \mathrm{c}$ & $160.44 \mathrm{c}$ \\
P5 & $2.67 \mathrm{bc}$ & $4.22 \mathrm{abc}$ & $9.67 \mathrm{~cd}$ & $22.00 \mathrm{ab}$ & $39.33 \mathrm{ab}$ & $68.56 \mathrm{bcd}$ & $104.56 \mathrm{bc}$ & $114.89 \mathrm{ab}$ \\
P6 & $2.33 \mathrm{abc}$ & $4.00 \mathrm{ab}$ & $8.89 \mathrm{abcd}$ & $18.89 \mathrm{a}$ & $38.78 \mathrm{ab}$ & $44.67 \mathrm{a}$ & $88.44 \mathrm{abc}$ & $147.22 \mathrm{bc}$ \\
P7 & $1.67 \mathrm{ab}$ & $3.22 \mathrm{a}$ & $9.11 \mathrm{bcd}$ & $13.89 \mathrm{a}$ & $26.78 \mathrm{ab}$ & $40.33 \mathrm{a}$ & $81.67 \mathrm{ab}$ & $86.11 \mathrm{a}$ \\
\hline LSD (5\%) & 1.27 & 1.71 & 3.68 & 9.28 & 23.17 & 22.56 & 55.66 & 37.93 \\
\hline C.V. (\%) & 34.04 & 24.39 & 26.42 & 27.99 & 33.94 & 21.04 & 39.02 & 19.91 \\
\hline
\end{tabular}

Note: Numbers accompanied by the same letter in the same row and column show no significant difference based on the LSD test at the 5\% level, $\mathrm{CV}=$ Coefficient of Variation, Day After Planting (DAP)

Table 4. Average leaf area for each observation age

\begin{tabular}{lllllllll}
\hline \multirow{2}{*}{$\begin{array}{l}\text { Treatment } \\
\text { (unit) }\end{array}$} & \multicolumn{6}{l}{ Leaf Area at The Age of Observation The Day After Planting (DAP) } \\
\cline { 2 - 9 } & 4 & 8 & 12 & 20 & 24 & 28 & 32 \\
\hline P0 & $8.48 \mathrm{ab}$ & $13.99 \mathrm{a}$ & $29.81 \mathrm{ab}$ & $57.25 \mathrm{a}$ & $117.78 \mathrm{a}$ & $264.09 \mathrm{a}$ & $268.7 \mathrm{a}$ & $472.31 \mathrm{a}$ \\
P1 & $11.39 \mathrm{bc}$ & $20.35 \mathrm{a}$ & $41.86 \mathrm{abc}$ & $88.82 \mathrm{abc}$ & $134.29 \mathrm{a}$ & $366.36 \mathrm{a}$ & $626.79 \mathrm{a}$ & $977.17 \mathrm{ab}$ \\
P2 & $11.17 \mathrm{bc}$ & $14.00 \mathrm{a}$ & $26.87 \mathrm{a}$ & $60.03 \mathrm{a}$ & $162.57 \mathrm{a}$ & $233.57 \mathrm{a}$ & $357.08 \mathrm{a}$ & $858.44 \mathrm{ab}$ \\
P3 & $13.41 \mathrm{c}$ & $14.62 \mathrm{a}$ & $24.21 \mathrm{a}$ & $74.48 \mathrm{ab}$ & $201.4 \mathrm{ab}$ & $303.68 \mathrm{a}$ & $316.38 \mathrm{a}$ & $467.17 \mathrm{a}$ \\
P4 & $13.19 \mathrm{c}$ & $33.57 \mathrm{~b}$ & $53.64 \mathrm{c}$ & $132.95 \mathrm{~d}$ & $314.95 \mathrm{~b}$ & $564.04 \mathrm{~b}$ & $1210.61 \mathrm{~b}$ & $1379.28 \mathrm{~b}$ \\
P5 & $11.42 \mathrm{bc}$ & $19.48 \mathrm{a}$ & $47.09 \mathrm{bc}$ & $107.74 \mathrm{~cd}$ & $213.52 \mathrm{ab}$ & $365.25 \mathrm{a}$ & $534.8 \mathrm{a}$ & $1099.36 \mathrm{~b}$ \\
P6 & $8.27 \mathrm{ab}$ & $18.10 \mathrm{a}$ & $35.17 \mathrm{ab}$ & $105.95 \mathrm{bcd}$ & $225.44 \mathrm{ab}$ & $262.339 \mathrm{a}$ & $382.59 \mathrm{a}$ & $956.58 \mathrm{ab}$ \\
P7 & $7.91 \mathrm{a}$ & $19.89 \mathrm{a}$ & $30.83 \mathrm{ab}$ & $86.68 \mathrm{abc}$ & $127.95 \mathrm{a}$ & $242.83 \mathrm{a}$ & $311.71 \mathrm{a}$ & $503.91 \mathrm{a}$ \\
\hline LSD (5\%) & 3.16 & 7.87 & 17.97 & 31.68 & 113.74 & 171.50 & 387.75 & 541.74 \\
\hline C.V. (\%) & 16.95 & 23.34 & 28.35 & 20.27 & 34.69 & 30.11 & 44.19 & 36.86 \\
\hline
\end{tabular}

Note: Numbers accompanied by the same letter in the same row and column show no significant difference based on the LSD test at the $5 \%$ level, $\mathrm{CV}=$ Coefficient of Variation, Day After Planting (DAP) 
Table 5. Average root length of each observation age

\begin{tabular}{|c|c|c|c|c|c|c|c|c|}
\hline \multirow{3}{*}{$\begin{array}{l}\text { Treatment } \\
\text { (unit) }\end{array}$} & \multicolumn{8}{|c|}{ Root Length at the age of Observation The Day After Planting (DAP) } \\
\hline & 4 & 8 & 12 & 16 & 20 & 24 & 28 & 32 \\
\hline & \multicolumn{8}{|l|}{$(\mathrm{cm})$} \\
\hline P0 & $6.02 \mathrm{a}$ & $6.44 \mathrm{a}$ & $7.07 \mathrm{a}$ & $7.31 \mathrm{a}$ & $10.19 \mathrm{ab}$ & $12.57 \mathrm{a}$ & $14.50 \mathrm{a}$ & $21.38 \mathrm{~cd}$ \\
\hline P1 & $6.64 \mathrm{a}$ & $6.92 \mathrm{a}$ & $7.18 \mathrm{a}$ & $7.57 \mathrm{a}$ & $10.49 \mathrm{ab}$ & $13.59 \mathrm{ab}$ & $12.96 \mathrm{a}$ & 13.89 a \\
\hline $\mathrm{P} 2$ & $7.17 \mathrm{a}$ & $7.39 \mathrm{a}$ & $7.86 \mathrm{a}$ & $9.08 \mathrm{a}$ & $13.97 \mathrm{c}$ & $15.50 \mathrm{bc}$ & $15.56 \mathrm{a}$ & $20.58 \mathrm{bcd}$ \\
\hline P3 & $6.90 \mathrm{a}$ & $6.87 \mathrm{a}$ & $7.39 \mathrm{a}$ & $7.68 \mathrm{a}$ & $11.13 \mathrm{abc}$ & $14.29 \mathrm{ab}$ & $12.26 \mathrm{a}$ & $14.01 \mathrm{a}$ \\
\hline $\mathrm{P} 4$ & $8.65 \mathrm{~b}$ & $9.67 \mathrm{~b}$ & $10.03 \mathrm{~b}$ & $11.78 \mathrm{~b}$ & $17.19 \mathrm{~d}$ & $22.32 \mathrm{~d}$ & $20.68 \mathrm{~b}$ & $23.85 \mathrm{~d}$ \\
\hline P5 & $6.85 \mathrm{a}$ & $6.93 \mathrm{a}$ & $7.57 \mathrm{a}$ & $8.99 \mathrm{a}$ & $11.88 \mathrm{abc}$ & $14.06 \mathrm{ab}$ & $13.92 \mathrm{a}$ & $15.91 \mathrm{a}$ \\
\hline P6 & $7.39 \mathrm{ab}$ & $7.99 a b$ & $8.50 \mathrm{ab}$ & $9.22 \mathrm{a}$ & $13.00 \mathrm{bc}$ & $17.72 \mathrm{c}$ & $16.03 \mathrm{a}$ & $16.77 \mathrm{ab}$ \\
\hline $\mathrm{P} 7$ & $6.73 \mathrm{a}$ & $7.00 \mathrm{a}$ & $7.90 \mathrm{a}$ & $8.56 \mathrm{a}$ & $10.03 \mathrm{a}$ & $13.43 \mathrm{ab}$ & $14.16 \mathrm{a}$ & $17.54 \mathrm{abc}$ \\
\hline LSD (5\%) & 1.39 & 1.70 & 1.54 & 2.31 & 2.91 & 2.90 & 4.18 & 4.11 \\
\hline C.V. $(\%)$ & 11.24 & 13.09 & 11.09 & 15.04 & 13.58 & 10.74 & 15.89 & 13.05 \\
\hline
\end{tabular}

Note: Numbers accompanied by the same letter in the same row and column show no significant difference based on the LSD test at the $5 \%$ level, $\mathrm{CV}=$ Coefficient of Variation, Day After Planting (DAP)

Table 6. Average stomata density

\begin{tabular}{llll}
\hline \multirow{2}{*}{$\begin{array}{l}\text { Treatment } \\
\text { (unit) }\end{array}$} & Number of Stomata & Stomata Width & Stomata Length \\
\cline { 3 - 4 } & & $(\mathrm{cm})$ & \\
\hline P0 & $8.08 \mathrm{a}$ & $6.31 \mathrm{a}$ & $12.39 \mathrm{a}$ \\
P1 & $9.92 \mathrm{abc}$ & $7.51 \mathrm{ab}$ & $15.66 \mathrm{~b}$ \\
P2 & $10.42 \mathrm{abc}$ & $8.18 \mathrm{abc}$ & $16.90 \mathrm{bc}$ \\
P3 & $11.83 \mathrm{~cd}$ & $8.39 \mathrm{abc}$ & $18.26 \mathrm{bc}$ \\
P4 & $13.25 \mathrm{~d}$ & $10.87 \mathrm{c}$ & $19.76 \mathrm{c}$ \\
P5 & $11.17 \mathrm{bcd}$ & $9.50 \mathrm{bc}$ & $16.85 \mathrm{bc}$ \\
P6 & $10.25 \mathrm{abc}$ & $7.70 \mathrm{ab}$ & $15.84 \mathrm{~b}$ \\
P7 & $8.75 \mathrm{ab}$ & $6.51 \mathrm{a}$ & $16.60 \mathrm{~b}$ \\
\hline LSD $(5 \%)$ & 2.61 & 2.69 & 3.03 \\
\hline C.V. (\%) & 14.25 & 18.93 & 10.47 \\
\hline
\end{tabular}

Note: Numbers accompanied by the same letter in the same row and column show no significant difference based on the LSD test at the $5 \%$ level, $\mathrm{CV}=$ Coefficient of Variation, Day After Planting (DAP) 
Table 7. Average leaf fresh weight for each observation age

\begin{tabular}{|c|c|c|c|c|c|c|c|c|}
\hline \multirow{3}{*}{$\begin{array}{l}\text { Treatment } \\
\text { (unit) }\end{array}$} & \multicolumn{8}{|c|}{ Leaf Fresh Weight at The Age of Observation The Day After Planting (DAP) } \\
\hline & 4 & 8 & 12 & 16 & 20 & 24 & 28 & 32 \\
\hline & \multicolumn{8}{|l|}{ (g) } \\
\hline $\mathrm{P} 0$ & $0.047 \mathrm{a}$ & $0.123 \mathrm{a}$ & $0.167 \mathrm{a}$ & $0.676 \mathrm{ab}$ & $1.332 \mathrm{ab}$ & $1.882 \mathrm{a}$ & $2.237 \mathrm{a}$ & $6.036 \mathrm{a}$ \\
\hline $\mathrm{P} 1$ & $0.069 \mathrm{ab}$ & $0.140 \mathrm{a}$ & $0.178 \mathrm{ab}$ & $0.717 \mathrm{ab}$ & $1.234 \mathrm{a}$ & $1.916 \mathrm{a}$ & $2.737 \mathrm{a}$ & $7.794 \mathrm{ab}$ \\
\hline $\mathrm{P} 2$ & 0.106 cde & $0.120 \mathrm{a}$ & $0.229 \mathrm{abc}$ & $0.660 \mathrm{a}$ & $1.469 \mathrm{ab}$ & $2.074 \mathrm{a}$ & $3.046 \mathrm{a}$ & $9.523 \mathrm{~b}$ \\
\hline P3 & $0.118 \mathrm{de}$ & $0.144 \mathrm{a}$ & $0.218 \mathrm{abc}$ & $0.766 \mathrm{ab}$ & $1.818 \mathrm{ab}$ & $2.687 \mathrm{ab}$ & $3.490 \mathrm{a}$ & $6.891 \mathrm{ab}$ \\
\hline $\mathrm{P} 4$ & $0.133 \mathrm{e}$ & $0.276 \mathrm{~b}$ & $0.514 \mathrm{~d}$ & $1.464 \mathrm{c}$ & $2.788 \mathrm{c}$ & $4.974 \mathrm{c}$ & $8.287 \mathrm{c}$ & $12.907 \mathrm{c}$ \\
\hline P5 & 0.101 bcde & $0.249 \mathrm{~b}$ & $0.366 \mathrm{~cd}$ & $1.050 \mathrm{~b}$ & $2.193 \mathrm{bc}$ & $3.832 \mathrm{bc}$ & $5.642 \mathrm{~b}$ & $9.834 \mathrm{~b}$ \\
\hline P6 & $0.083 \mathrm{bc}$ & $0.129 \mathrm{a}$ & $0.340 \mathrm{bc}$ & $0.861 \mathrm{ab}$ & $1.956 \mathrm{abc}$ & $2.663 \mathrm{ab}$ & $4.129 \mathrm{ab}$ & $7.62 \mathrm{ab}$ \\
\hline P7 & $0.091 \mathrm{bcd}$ & $0.138 \mathrm{a}$ & $0.301 \mathrm{abc}$ & $0.512 \mathrm{a}$ & $1.420 \mathrm{ab}$ & $2.247 \mathrm{a}$ & $3.404 \mathrm{a}$ & $7.153 \mathrm{ab}$ \\
\hline $\operatorname{LSD}(5 \%)$ & 0.03 & 0.06 & 0.11 & 0.38 & 0.90 & 1.25 & 1.90 & 3.00 \\
\hline C.V. $(\%)$ & 10.46 & 19.29 & 32.37 & 25.95 & 28.93 & 25.55 & 26.97 & 20.22 \\
\hline
\end{tabular}

Note: Numbers accompanied by the same letter in the same row and column show no significant difference based on the LSD test at the $5 \%$ level, $\mathrm{CV}=$ Coefficient of Variation, Day After Planting (DAP)

Table 8. Average leaf dry weight for each observation age

\begin{tabular}{lllllllll}
\hline \multirow{2}{*}{$\begin{array}{l}\text { Treatment } \\
\text { (unit) }\end{array}$} & \multicolumn{7}{l}{ Leaf Dry Weight at The Age of Observation The Day After Planting (DAP) } \\
\cline { 2 - 8 } & 4 & 8 & 12 & 16 & 20 & 24 & 28 & 32 \\
\hline P0 & $0.015 \mathrm{a}$ & $0.022 \mathrm{a}$ & $0.030 \mathrm{a}$ & $0.082 \mathrm{a}$ & $0.185 \mathrm{a}$ & $0.380 \mathrm{a}$ & $0.437 \mathrm{a}$ & $0.671 \mathrm{a}$ \\
P1 & $0.016 \mathrm{ab}$ & $0.230 \mathrm{a}$ & $0.043 \mathrm{a}$ & $0.097 \mathrm{ab}$ & $0.212 \mathrm{ab}$ & $0.432 \mathrm{ab}$ & $0.481 \mathrm{a}$ & $0.915 \mathrm{ab}$ \\
P2 & $0.026 \mathrm{bc}$ & $0.027 \mathrm{a}$ & $0.057 \mathrm{ab}$ & $0.125 \mathrm{ab}$ & $0.219 \mathrm{ab}$ & $0.476 \mathrm{ab}$ & $0.396 \mathrm{a}$ & $1.318 \mathrm{bc}$ \\
P3 & $0.028 \mathrm{~cd}$ & $0.032 \mathrm{a}$ & $0.099 \mathrm{abc}$ & $0.103 \mathrm{ab}$ & $0.316 \mathrm{bc}$ & $0.576 \mathrm{bc}$ & $0.746 \mathrm{ab}$ & $1.101 \mathrm{ab}$ \\
P4 & $0.047 \mathrm{e}$ & $0.198 \mathrm{~b}$ & $0.183 \mathrm{c}$ & $0.216 \mathrm{c}$ & $0.496 \mathrm{~d}$ & $0.866 \mathrm{~d}$ & $1.442 \mathrm{c}$ & $1.802 \mathrm{c}$ \\
P5 & $0.037 \mathrm{de}$ & $0.041 \mathrm{a}$ & $0.139 \mathrm{bc}$ & $0.218 \mathrm{c}$ & $0.449 \mathrm{~d}$ & $0.673 \mathrm{c}$ & $1.018 \mathrm{~b}$ & $1.269 \mathrm{bc}$ \\
P6 & $0.029 \mathrm{~cd}$ & $0.028 \mathrm{a}$ & $0.088 \mathrm{ab}$ & $0.150 \mathrm{~b}$ & $0.390 \mathrm{~cd}$ & $0.457 \mathrm{ab}$ & $0.594 \mathrm{a}$ & $1.119 \mathrm{ab}$ \\
P7 & $0.020 \mathrm{abc}$ & $0.340 \mathrm{a}$ & $0.054 \mathrm{ab}$ & $0.110 \mathrm{ab}$ & $0.280 \mathrm{abc}$ & $0.468 \mathrm{ab}$ & $0.577 \mathrm{a}$ & $0.990 \mathrm{ab}$ \\
\hline LSD (5\%) & 0.01 & 0.2 & 0.09 & 0.07 & 0.13 & 0.17 & 0.36 & 0.58 \\
\hline C.V. (\%) & 9.943 & 15.557 & 58.897 & 27.390 & 23.139 & 17.831 & 29.074 & 28.907 \\
\hline
\end{tabular}

Note: Numbers accompanied by the same letter in the same row and column show no significant difference based on the LSD test at the $5 \%$ level, $\mathrm{CV}=$ Coefficient of Variation, Day After Planting (DAP) 
Table 9. Average total fresh weight for each observation age

\begin{tabular}{lllllllll}
\hline \multirow{2}{*}{$\begin{array}{l}\text { Treatment } \\
\text { (unit) }\end{array}$} & \multicolumn{7}{l}{ Total Fresh Weight at The Age of Observation The Day After Planting (DAP) } \\
\cline { 2 - 9 } & 4 & (g) & 8 & 12 & 20 & 24 & 28 & 32 \\
\hline P0 & $0.280 \mathrm{a}$ & $0.598 \mathrm{a}$ & $0.783 \mathrm{a}$ & $1.669 \mathrm{a}$ & $4.907 \mathrm{ab}$ & $7.288 \mathrm{a}$ & $82.106 \mathrm{ab}$ & $131.223 \mathrm{abc}$ \\
P1 & $0.290 \mathrm{a}$ & $0.621 \mathrm{a}$ & $0.944 \mathrm{ab}$ & $1.862 \mathrm{a}$ & $5.083 \mathrm{ab}$ & $7.668 \mathrm{a}$ & $137.350 \mathrm{bc}$ & $182.084 \mathrm{bcd}$ \\
P2 & $0.432 \mathrm{~b}$ & $0.657 \mathrm{ab}$ & $1.110 \mathrm{abc}$ & $2.367 \mathrm{ab}$ & $4.609 \mathrm{a}$ & $8.580 \mathrm{a}$ & $75.011 \mathrm{a}$ & $190.703 \mathrm{~cd}$ \\
P3 & $0.467 \mathrm{~b}$ & $0.747 \mathrm{ab}$ & $1.208 \mathrm{bc}$ & $2.390 \mathrm{ab}$ & $6.572 \mathrm{ab}$ & $9.811 \mathrm{a}$ & $81.830 \mathrm{ab}$ & $116.142 \mathrm{ab}$ \\
P4 & $0.643 \mathrm{c}$ & $1.199 \mathrm{c}$ & $1.867 \mathrm{~d}$ & $3.866 \mathrm{c}$ & $9.396 \mathrm{c}$ & $17.221 \mathrm{c}$ & $193.770 \mathrm{c}$ & $210.830 \mathrm{~d}$ \\
P5 & $0.419 \mathrm{~b}$ & $0.832 \mathrm{~b}$ & $1.511 \mathrm{~cd}$ & $3.116 \mathrm{bc}$ & $7.377 \mathrm{bc}$ & $13.189 \mathrm{~b}$ & $106.970 \mathrm{ab}$ & $157.941 \mathrm{abcd}$ \\
P6 & $0.449 \mathrm{~b}$ & $0.713 \mathrm{ab}$ & $1.439 \mathrm{c}$ & $2.983 \mathrm{bc}$ & $7.043 \mathrm{abc}$ & $9.981 \mathrm{a}$ & $104.650 \mathrm{ab}$ & $186.274 \mathrm{~cd}$ \\
P7 & $0.450 \mathrm{~b}$ & $0.690 \mathrm{ab}$ & $1.191 \mathrm{abc}$ & $2.053 \mathrm{a}$ & $5.705 \mathrm{ab}$ & $7.438 \mathrm{a}$ & $88.891 \mathrm{ab}$ & $102.482 \mathrm{a}$ \\
\hline LSD (5\%) & 0.07 & 0.21 & 0.41 & 0.90 & 2.54 & 3.20 & 57.86 & 69.54 \\
\hline C.V. (\%) & 32.043 & 25.901 & 18.709 & 20.176 & 22.922 & 18.008 & 30.364 & 24.863 \\
\hline
\end{tabular}

Note: Numbers accompanied by the same letter in the same row and column show no significant difference based on the LSD test at the 5\% level, $\mathrm{CV}=$ Coefficient of Variation, Day After Planting (DAP)

Table 10. Average total dry weight of each observation age

\begin{tabular}{lllllllll}
\hline \multirow{2}{*}{$\begin{array}{l}\text { Treatment } \\
\text { (unit) }\end{array}$} & \multicolumn{7}{l}{ Total Dry Weight at The Age of Observation The Day After Planting (DAP) } \\
\cline { 2 - 8 } & 4 & 8 & 12 & 16 & 20 & 24 & 28 & 32 \\
\hline P0 & $0.053 \mathrm{a}$ & $0.087 \mathrm{a}$ & $0.117 \mathrm{a}$ & $0.220 \mathrm{a}$ & $0.473 \mathrm{a}$ & $1.096 \mathrm{a}$ & $1.562 \mathrm{a}$ & $2.653 \mathrm{a}$ \\
P1 & $0.063 \mathrm{ab}$ & $0.098 \mathrm{ab}$ & $0.152 \mathrm{ab}$ & $0.251 \mathrm{a}$ & $0.520 \mathrm{a}$ & $1.273 \mathrm{ab}$ & $1.721 \mathrm{a}$ & $3.433 \mathrm{ab}$ \\
P2 & $0.112 \mathrm{~cd}$ & $0.117 \mathrm{abc}$ & $0.196 \mathrm{ab}$ & $0.328 \mathrm{ab}$ & $0.722 \mathrm{ab}$ & $1.415 \mathrm{ab}$ & $1.665 \mathrm{a}$ & $5.597 \mathrm{c}$ \\
P3 & $0.134 \mathrm{de}$ & $0.165 \mathrm{~cd}$ & $0.274 \mathrm{bc}$ & $0.334 \mathrm{ab}$ & $1.172 \mathrm{~cd}$ & $1.898 \mathrm{~cd}$ & $2.169 \mathrm{ab}$ & $3.697 \mathrm{ab}$ \\
P4 & $0.149 \mathrm{e}$ & $0.206 \mathrm{~d}$ & $0.485 \mathrm{~d}$ & $0.603 \mathrm{~d}$ & $1.588 \mathrm{e}$ & $3.011 \mathrm{e}$ & $4.829 \mathrm{c}$ & $7.823 \mathrm{~d}$ \\
P5 & $0.129 \mathrm{de}$ & $0.166 \mathrm{~cd}$ & $0.383 \mathrm{~cd}$ & $0.509 \mathrm{~cd}$ & $1.279 \mathrm{cde}$ & $2.132 \mathrm{~d}$ & $3.058 \mathrm{~b}$ & $4.789 \mathrm{bc}$ \\
P6 & $0.098 \mathrm{bcd}$ & $0.123 \mathrm{abc}$ & $0.215 \mathrm{ab}$ & $0.458 \mathrm{bc}$ & $1.375 \mathrm{de}$ & $1.682 \mathrm{bc}$ & $2.402 \mathrm{ab}$ & $5.277 \mathrm{bc}$ \\
P7 & $0.089 \mathrm{abc}$ & $0.144 \mathrm{bc}$ & $0.184 \mathrm{ab}$ & $0.312 \mathrm{a}$ & $0.931 \mathrm{bc}$ & $1.502 \mathrm{abc}$ & $2.137 \mathrm{ab}$ & $3.900 \mathrm{abc}$ \\
\hline LSD (5\%) & 0.04 & 0.15 & 0.15 & 0.13 & 0.41 & 0.41 & 1.33 & 1.86 \\
\hline C.V. (\%) & 20.361 & 20.695 & 34.074 & 20.209 & 23.050 & 13.315 & 30.982 & 22.892 \\
\hline
\end{tabular}

Note: Numbers accompanied by the same letter in the same row and column show no significant difference based on the LSD test at the $5 \%$ level, $\mathrm{CV}=$ Coefficient of Variation, Day After Planting (DAP) 
Table 11. Average harvest fresh weight at 32 DAP

\begin{tabular}{|c|c|c|c|c|}
\hline \multirow{3}{*}{$\begin{array}{l}\text { Treatment } \\
\text { (unit) }\end{array}$} & \multicolumn{4}{|c|}{ Harvest Fresh Weight at 32 DAP } \\
\hline & Leaf & Stalk & Root & Total \\
\hline & \multicolumn{4}{|l|}{$(\mathrm{g})$} \\
\hline $\mathrm{P} 0$ & $18.18 \mathrm{a}$ & $58.27 \mathrm{a}$ & $35.13 \mathrm{a}$ & $111.57 \mathrm{a}$ \\
\hline $\mathrm{P} 1$ & $20.88 \mathrm{ab}$ & $69.92 \mathrm{ab}$ & $41.22 \mathrm{ab}$ & $132.02 \mathrm{ab}$ \\
\hline $\mathrm{P} 2$ & $32.86 \mathrm{~b}$ & $61.31 \mathrm{a}$ & $47.52 \mathrm{ab}$ & $141.70 \mathrm{ab}$ \\
\hline P3 & $32.64 \mathrm{~b}$ & $63.31 \mathrm{a}$ & $51.43 \mathrm{ab}$ & $147.38 \mathrm{ab}$ \\
\hline P4 & $64.19 \mathrm{~d}$ & $130.54 \mathrm{c}$ & $79.75 \mathrm{c}$ & $274.48 \mathrm{~d}$ \\
\hline P5 & $58.33 \mathrm{~cd}$ & $113.58 \mathrm{bc}$ & $64.02 \mathrm{bc}$ & $235.92 \mathrm{~cd}$ \\
\hline P6 & $51.99 \mathrm{~cd}$ & $71.23 \mathrm{ab}$ & $62.47 \mathrm{bc}$ & $185.69 \mathrm{bc}$ \\
\hline P7 & $46.67 \mathrm{c}$ & $85.54 \mathrm{ab}$ & $49.43 \mathrm{ab}$ & $181.65 \mathrm{bc}$ \\
\hline $\operatorname{LSD}(5 \%)$ & 12.62 & 44.44 & 23.01 & 55.99 \\
\hline C.V. $(\%)$ & 17.70 & 31.06 & 24.39 & 18.13 \\
\hline
\end{tabular}

Note: Numbers accompanied by the same letter in the same row and column show no significant difference based on the LSD test at the 5\% level, $\mathrm{CV}=$ Coefficient of Variation, Day After Planting (DAP)

Table 12. Average harvest dry weight at 32 DAP

\begin{tabular}{|c|c|c|c|c|}
\hline \multirow{3}{*}{$\begin{array}{l}\text { Treatment } \\
\text { (unit) }\end{array}$} & \multicolumn{4}{|c|}{ Harvest Dry Weight at 32 DAP } \\
\hline & Leaf & Stalk & Root & Total \\
\hline & \multicolumn{4}{|l|}{ (g) } \\
\hline $\mathrm{P} 0$ & $5.40 \mathrm{a}$ & $12.49 \mathrm{ab}$ & $3.09 \mathrm{a}$ & $20.98 \mathrm{a}$ \\
\hline $\mathrm{P} 1$ & $6.21 \mathrm{a}$ & $15.34 \mathrm{abc}$ & $4.10 \mathrm{a}$ & $25.64 \mathrm{ab}$ \\
\hline $\mathrm{P} 2$ & $6.46 \mathrm{a}$ & $12.91 \mathrm{ab}$ & $5.24 \mathrm{ab}$ & $24.61 \mathrm{ab}$ \\
\hline P3 & $7.93 \mathrm{ab}$ & $11.99 \mathrm{a}$ & $6.53 \mathrm{abc}$ & $26.47 \mathrm{ab}$ \\
\hline P4 & $11.36 \mathrm{c}$ & $24.88 \mathrm{~d}$ & $9.55 \mathrm{c}$ & $45.78 \mathrm{~d}$ \\
\hline P5 & $10.43 \mathrm{bc}$ & $20.44 \mathrm{~cd}$ & $8.74 \mathrm{bc}$ & $39.61 \mathrm{~cd}$ \\
\hline P6 & $7.44 \mathrm{ab}$ & $16.97 \mathrm{abc}$ & $4.95 \mathrm{ab}$ & $29.37 \mathrm{ab}$ \\
\hline P7 & $8.08 \mathrm{ab}$ & $17.80 \mathrm{bc}$ & $5.23 \mathrm{ab}$ & $31.10 \mathrm{bc}$ \\
\hline $\operatorname{LSD}(5 \%)$ & 3.09 & 5.41 & 3.81 & 8.97 \\
\hline C.V. (\%) & 22.31 & 18.59 & 36.72 & 16.82 \\
\hline
\end{tabular}

Note: Numbers accompanied by the same letter in the same row and column show no significant difference based on the LSD test at the $5 \%$ level, $\mathrm{CV}=$ Coefficient of Variation, Day After Planting (DAP)

Table 13. Average chlorophyll content

\begin{tabular}{llll}
\hline $\begin{array}{l}\text { Treatment } \\
\text { (unit) }\end{array}$ & \multicolumn{1}{c}{ chlorophyll a } & chlorophyll b \\
\cline { 2 - 4 }$\left(\mathrm{mg}^{-1}\right)$ & & $0.826 \mathrm{a}$ & $1.523 \mathrm{a}$ \\
P0 & $0.697 \mathrm{a}$ & $0.879 \mathrm{~b}$ & $1.581 \mathrm{~b}$ \\
P1 & $0.701 \mathrm{a}$ & $0.901 \mathrm{~b}$ & $1.633 \mathrm{c}$ \\
P2 & $0.733 \mathrm{~b}$ & $0.952 \mathrm{c}$ & $1.719 \mathrm{de}$ \\
P3 & $0.762 \mathrm{de}$ & $1.121 \mathrm{f}$ & $1.924 \mathrm{~g}$ \\
P4 & $0.804 \mathrm{f}$ & $1.051 \mathrm{e}$ & $1.821 \mathrm{f}$ \\
P5 & $0.771 \mathrm{e}$ & $0.994 \mathrm{~d}$ & $1.744 \mathrm{e}$ \\
P6 & $0.752 \mathrm{~cd}$ & $0.939 \mathrm{c}$ & $1.680 \mathrm{~cd}$ \\
P7 & $0.742 \mathrm{bc}$ & 33.34 & 46.73 \\
\hline LSD (5\%) & 15.94 & 1.98 & 1.56 \\
\hline C.V. $(\%)$ & 1.22 & and
\end{tabular}

Note: Numbers accompanied by the same letter in the same row and column show no significant difference based on the LSD test at the $5 \%$ level, $\mathrm{CV}=$ Coefficient of Variation 